\title{
Cave bats of the central west coast and southern section of the Northwest Panay Peninsula, Panay Island, the Philippines
}

\author{
Antony Mould
}

Philippine Spotted Deer Conservation Foundation, Villa Tinigbas, Barangay Tinigbas, Libertad Municipality, Antique Province, Panay Island, Philippines 5710

Email: antonymould@hotmail.com

\begin{abstract}
Bats (order Chiroptera) form a large proportion of the species-rich mammalian fauna of the Philippines, and while the threats posed to these animals are well documented, for many species there is currently insufficient data to enable even a basic assessment of their conservation status. This is true for Panay Island, located in the Western Visayas region of the archipelago, where the need for surveying remaining suitable bat habitat has been identified as a priority. Between 5 April and 9 May 2011 a survey of 21 caves was undertaken on Panay, along the central section of the west coast of the island and within the southern section of the Northwest Panay Peninsula. Survey methods included visual observations, emergence counts and the recording of echolocation calls. Of the caves surveyed, 19 were found to support bats or show signs of their use, and at least 12 different species were observed. Three large maternity colonies of the Common Rousette Rousettus amplexicaudatus and two of the Dusky Roundleaf Bat Hipposideros ater were noted as having particular significance in terms of their conservation value for local populations. Potential maternity colonies of Asian Lesser False Vampire Megaderma spasma, Black-bearded Tomb Bat Taphozous melanopogon and Diadem Roundleaf Bat Hipposideros diadema were also observed but not confirmed. M. spasma was the most frequently encountered species, occurring in small numbers at five different caves. Other species/genera encountered in small numbers were the Arcuate Horseshoe Bat Rhinolophus arcuatus, Common Short-nosed Fruit Bat Cynopterus brachyotis, Philippine Sheath-tailed Bat Emballonura alecto, Yellow-faced Horseshoe Bat Rhinolophus virgo, Bent-wing (Miniopterus) and Myotis bat species, and at least one other Horseshoe (Rhinolophus) bat species. Ten of the caves were confirmed to support multiple bat species. An indication of current threats and recommendations for further survey and management priorities are provided.
\end{abstract}

Keywords: Bat, cave, Hipposideros ater, Panay, Philippines, Rousettus amplexicaudatus

Date of publication (online): 26 September 2012 Date of publication (print): 26 September 2012 ISSN 0974-7907 (online) | 0974-7893 (print)

Editor: Dave Waldien

Manuscript details:

Ms \# 03104

Received 19 February 2012

Final received 03 June 2012

Finally accepted 26 August 2012

Citation: Mould, A. (2012). Cave bats of the central west coast and southern section of the Northwest Panay Peninsula, Panay Island, the Philippines. Journal of Threatened Taxa 4(11) 2993-3028.

Copyright: (c) Antony Mould 2012. Creative Commons Attribution 3.0 Unported License. JoTT allows unrestricted use of this article in any medium for non-profit purposes, reproduction and distribution by providing adequate credit to the authors and the source of publication.

Author Details and Acknowledgements: See end of this article
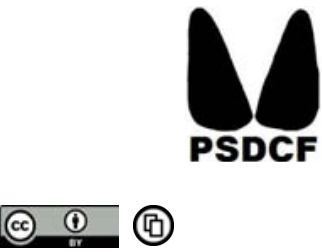

OPEN ACGESS | FREE DOWNLOAD
Tagalog Abstract (National language of the Philippines). Abstraksyion: Ang mga paniki (order Chiroptera) ay maraming klase at malaking parte na mamal na hayop sa Pilipinas. Na dukomenta na ang mga pusible at delekadong sitwasyon sa mga hayop na ito, pero sa karamihan sa kanila kulang parin ang mga besik na data para malaman natin ang mga konserbasyon status nila. Ito ang katutuhanan sa isla ng Panay sa kanluran ng visaya sa arkipelago. Dito ang naging prioridad na ma survey and mga natitirang tirahan ng mga paniki. Nuong a singko ng Abril hangang a nuebe ng Mayo 2011 sinurvey and benti uno na kweba sa Panay na nasa central kanluran sa dalampasigan hangang sa timog ng ilalim na seksyon ng hilagang kanluran ng Panay peninsula. Ang mga ginamit na pang survey ay pag tingin, pag bilang bago mag dilim, at rekording ng mga ingay at tawag nila. Sa mga kweba na sinurvey, disinuebe ang may laman na paniki o may sinyales na may paniki, at dose na klase na paniki ang na obserba. Tatlong may mga anak na kolony ng Rousettus amplexicaudatus at dalawang Hipposideros ater ang na obserba. Ito ay may importanteng signipikanse sa konserbasyon ng local na papulasyon ng mga klaseng paniking ito. Baka meron ding may manga anak na kolony ng Megaderma spasma, Taphozous melanopogon at Hipposideros diadema pero hindi ito na konpirma. M. spasma ay nakita sa limang kweba pero maliit lang ang mga papulasyon nito. Ang ibang mga species/genera na nakita pero konti lang sila ay ang Rhinolophus arcuatus, Cynopterus brachyotis, Emballonura alecto, Rhinolophus virgo, Miniopterus at Myotis species. At meron ding Rhinolophus species. Sampong mga kweba ang may maraming species na paniki. Indikasyon ng mga kasalukuyang pagbabanta at rekomendasyon para sa susunod na survey at pamamahala na prioridad ay sinama.
Abbreviations: $\mathrm{BCI}$ - Bat Conservation International; CF - Constant Frequency; DENR - Department of Environment and Natural Resources; IUCN - International Union for the Conservation of Nature; FM - Frequency Modulation; PESCP - Philippine Endemic Species Conservation Project; PSDCF - Philippine Spotted Deer Conservation Foundation. 


\section{INTRODUCTION}

The mammalian fauna of the Philippines is considered to be one of the most species-rich in the world, with a high level of endemism; unfortunately, it is also one of the most extensively endangered (Heaney 1993; Heaney et al. 1998). A large proportion of this fauna comprises bats (order Chiroptera) with currently 79 described species from seven families (Heaney et al. 2010). New species are still being discovered, such as the Mindoro stripe-faced Fruit Bat Styloctenium mindorensis (Esselstyn 2007), and uncertainties regarding the status of a number of currently recognised species and subspecies within genera including Cynopterus, Hipposideros and Rhinolophus suggest that new species are also likely to be described in the future (e.g., Campbell et al. 2004; Heaney et al. 2010).

Over 40 species of Philippine bats roost in caves (Heaney et al. 2010). The threats to these species are well known, ranging from direct impacts (destruction of caves through development pressure, disturbance of roost sites through insensitive tourism activities, harvesting of bats as a local source of food and collection of guano) to additional indirect pressures such as loss of foraging habitat from ongoing deforestation (e.g., Mickleburgh et al. 1992; Mendoza \& Mallari 1997; Hutson et al. 2001). Despite these known and increasing threats, for many species there is currently insufficient data (location of caves and the species they support, population estimates and trends, local threats) to enable even a basic assessment of their conservation status (Oliver \& Heaney 1996; Heaney \& Regalado 1998; O’Malley et al. 2006; Turner et al. 2006; Heaney et al. 2010). Islands and caves in particular have been identified as two crucial issues where co-ordinated actions are required to ensure the survival of bats, but which currently receive insufficient attention from many conservationists (Mickleburgh et al. 2002).

Within the Philippines, the mammalian fauna of the Greater Negros-Panay Faunal Region is the most threatened (Heaney 1993; Heaney \& Regalado 1998). As of 2009, 464 caves were known from the faunal region, representing $22 \%$ of all caves recorded within the Philippines (DENR-PAWB 2009). Panay Island lies in the west of the region and covers an area of $12,300 \mathrm{~km}^{2}$ (see Fig. 1). Historically, Panay was covered in tropical rainforest, and while the island has the largest remaining forested areas in the region, only $8 \%$ of the original forest cover remains (Pedregosa 2005). The majority of the remaining forest is now included within protected areas in some sections of the Central Panay Mountain Range and the Northwest Panay Peninsula Natural Park, and the Haribon Foundation is actively working on the process of protecting the whole of the Central Panay Mountain Range (R. Galang pers. comm. 20 March 2012). However, despite ongoing efforts at a legislation and policy level, there is insufficient government funding to enable non-governmental organisations and academic agencies to achieve effective conservation of protected areas or the endangered habitats and species they support on the ground (Pedregosa 2005; Subade \& Jugado 2010). Records of caves on the island are limited, and focused within the provinces of Aklan, Capiz, Iloilo and the central-eastern area of Antique (DENR-PAWB 2009).

In terms of mammal diversity, 29 species have been documented on the island, of which 20 are bats (Heaney et al. 2000). In comparison 49 species of mammals have been recorded on Negros (an island of similar size and biogeographic history) suggesting that the fauna of Panay is yet to be fully documented (Heaney at al. 2000). Research activity on the fauna and flora of the island has recently been increasing thanks to the efforts of organisations such as the nowlapsed Philippine Endemic Species Conservation Project (PESCP) and the Philippine Spotted Deer Conservation Foundation (PSDCF) (e.g., Curio et al. 1996; Klop et al. 1998; Gaulke \& Curio 2001; Galang $\&$ Madulid 2006). While a limited amount of work has been undertaken into the bats of Panay (e.g., Reiter \& Curio 2001; Reiter et al. 2006), little has focused on the distribution and status of species within the island. There is thus a clear need to survey suitable remaining habitats (forests and caves) to identify significant bat populations and assess their conservation importance (O'Malley et al. 2006). Such information should then be used to inform the conservation action that is required (Heaney et al. 2000).

During 2011, PSDCF initiated a programme of surveys on bat populations within local caves of western Panay to begin to address the existing lack of baseline information for the island. Specifically, the aims of this study were to determine the species 


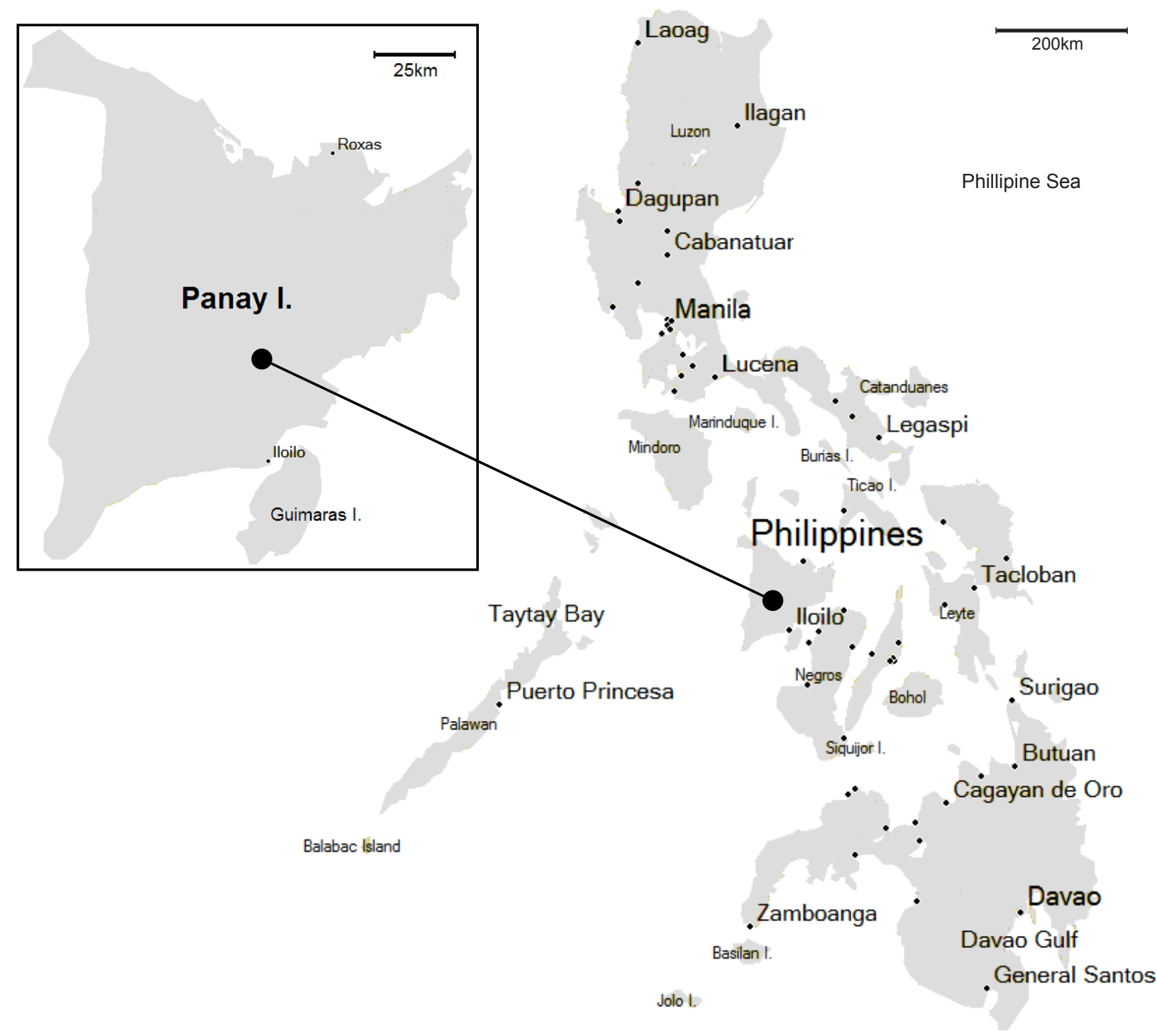

Figure 1. The Philippines, showing Panay Island

of bats observed within caves, estimate the numbers present, and record ecological information such as roosting preferences, indications of reproduction, and echolocation calls. This information could then be used to provide baseline data to the DENR for their formal survey and assessment work under the National Caves and Cave Resources Management and Protection Act of 2001, provide an assessment of current risks and provide recommendations for further survey work and management requirements where necessary.

\section{MATERIALS AND METHODS}

\section{Study Area}

Survey effort was focused in the province of Antique, and in particular the municipality of Libertad around the southern coast of the Northwest Panay Peninsula, where the PSDCF has its base of operations. However, specific expeditions were also undertaken to the northern section of the Central Panay Mountain Range in Ibajay, Aklan, as well as the municipalities of Culasi (including Malalison Island) and Barbaza on the west coast of the island. Locations of the survey areas are shown in Fig. 2. 

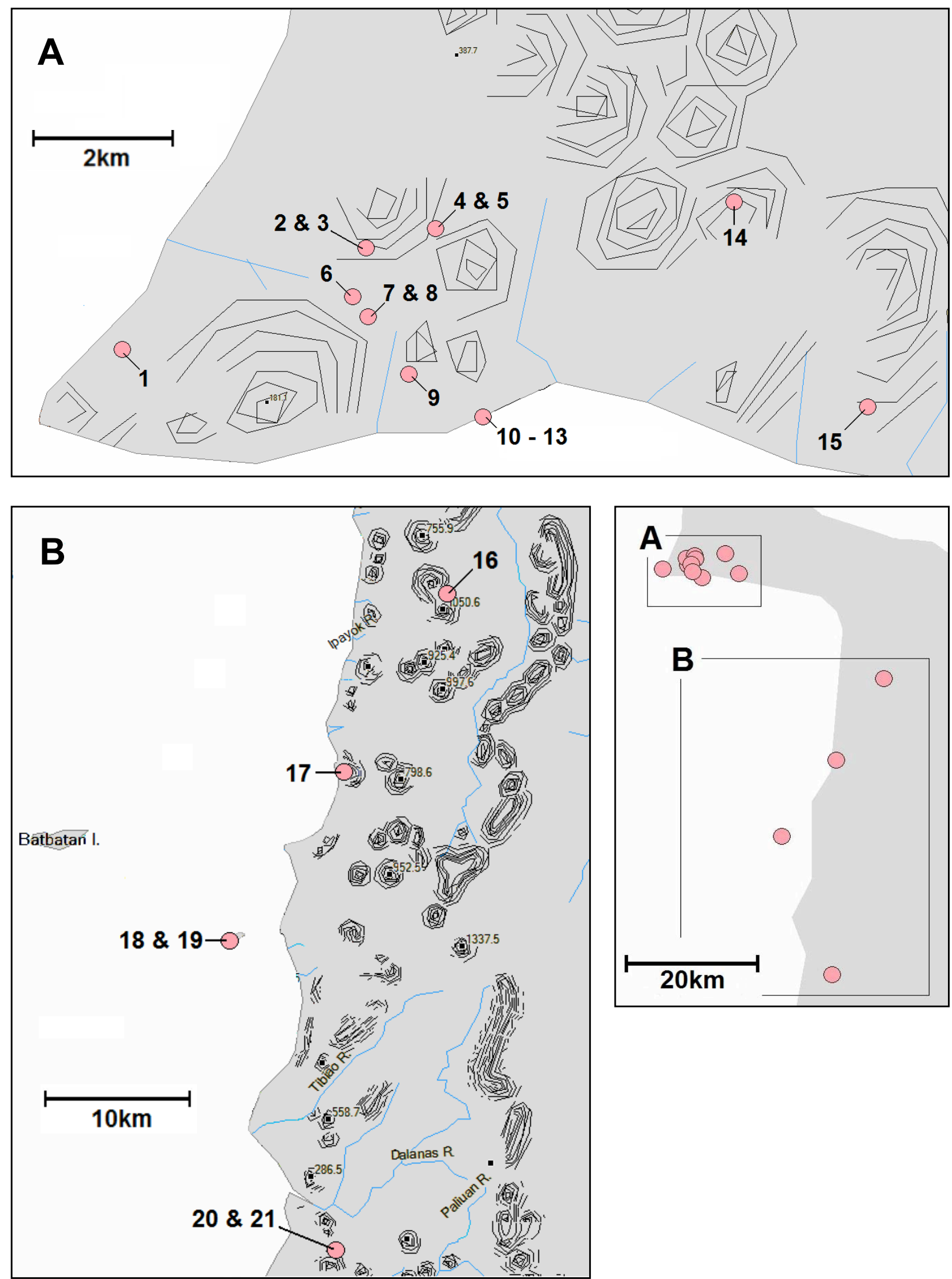

Figure 2. Locations of surveyed caves on Panay Island. Numbered pink circles refer to specific cave locations, black lines indicate topographic features (with heights measured as metres above mean sea level), and blue lines indicate major water courses 


\section{Cave Surveys}

Between 5 April and 9 May 2011 a total of 21 caves were visited. Caves were identified through discussions with various sources (local barangay officials and guides, landowners, municipality environment officers and mayors, and DENR staff), or had already been located through previous PSDCF expeditions.

Once identified, caves were visited with the help of local guides and explored as far as was practical, in survey teams of between two to seven people. In Barbaza the local guides were aware of several additional caves in the area, but were unable to locate them during the survey trip. Cave location coordinates were recorded using a Garmin GPSMAP 76CSx receiver (serial no. 76405972), and plotted using Mapsource Version 4.0 (Garmin Ltd). For each cave an initial, rapid assessment was undertaken, taking up to an hour to complete depending on the size of the cave. During the assessment rough descriptions of cave features and approximate dimensions were written down and sketched, and the presence of any notable fauna was recorded. In addition, signs of disturbance (such as graffiti and treasure-hunting) were recorded, along with any anecdotal information from guides, landowners or local officials (mayors, municipal environment officers, DENR staff) on current activities within the caves (such as tourism and bat harvesting).

All survey and specimen collection activities were undertaken under Gratuitous Permit R6-2011-06. Where bats were encountered, photographs and visual observations (such as roosting location and presence of juveniles) were made, and species were subsequently identified using Ingle \& Heaney (1992) and Heaney et al. (2010). When dead bats were found, these were collected and relevant measurements (as described in Ingle \& Heaney 1992) were taken using callipers to further aid identification. Where feasible, estimates of bat numbers were made by visual observation, or where large colonies of bats were present, numbers were estimated by undertaking subsequent evening emergence surveys outside cave entrances. The method followed that described by Churchill (2008) - at least two observers were positioned at suitable vantage points outside cave entrances prior to dusk, and the number of bats flying out were tallied until emergence activity ceased. Two methods of counting were employed, depending on the visual circumstances at the cave: (i) full counts of all bats seen emerging, (ii) bat emergence rates were established using sample one-minute emergence counts, and then multiplied by the total colony emergence time to provide an overall estimate of numbers. A Batbox Duet frequency division bat detector was used to help confirm species identification of large fruit bat colonies during cave assessments and emergence counts - Rousettus is the only genus of fruit bat that echolocates (Dumont 2003), and in the Philippines the genus is represented by a single species, the Common Rousette Rousettus amplexicaudatus (Heaney et al. 2010). Whilst $R$. amplexicaudatus could therefore be confirmed within large colonies through the detection of echolocation calls, it was not possible to determine whether other fruit bat species were also present - for example, $R$. amplexicaudatus is often found roosting in association with the Common Nectar Bat Eonycteris spelaea (Payne \& Francis 2005).

Echolocation recordings were obtained from freeflying individuals within the caves to aid with the identification of species that were difficult to confirm visually, particularly horseshoe bats (Rhinolophus sp.). Recordings were made using a Batbox Duet frequency division bat detector attached to an iRiver T20 MP3 recording device. The resulting MP3 files were converted to WAV files using JetAudio 6.1 (JetAudio Inc) to enable an analysis of sonograms using BatSound Standard - Sound Analysis Version 3.31 (Pettersson Elektronik AB). Analysis focused on call type (Constant Frequency (CF), Frequency Modulation (FM)) and call frequency $(\mathrm{KHz})$, where calls are defined as discreet echolocation pulses separated by inter-pulse intervals within a call sequence. There is currently no reference library for Panay bat echolocation calls; however, comparison was made with calls from previous studies of bat echolocation calls recorded elsewhere in the Philippines, in central Luzon (Sedlock 2001).

Where bats were not encountered, but other evidence of current or former occupancy (piles of guano, staining on walls) was present, this was noted down. Caves showing no signs of current or former occupancy were also recorded. 


\section{RESULTS}

Of the 21 caves that were visited, 19 were either found to support bats or evidence of their occupancy was observed. A total of nine species were positively identified, and at least another three were observed but only identified to genus level. Five large maternity roosts were confirmed, three of the Common Rousette Rousettus amplexicaudatus and two of the Dusky Roundleaf Bat Hipposideros ater. In addition, potential maternity colonies of Asian Lesser False Vampire Megaderma spasma, Black-bearded Tomb Bat Taphozous melanopogon and Diadem Roundleaf Bat Hipposideros diadema were observed but not confirmed. M. spasma was the most frequently encountered species, occurring in small numbers at five different caves. Other species/genera encountered in small numbers were the Arcuate Horseshoe Bat Rhinolophus arcuatus, Common Short-nosed Fruit Bat Cynopterus brachyotis, Philippine Sheath-tailed Bat Emballonura alecto, Yellow-faced Horseshoe Bat Rhinolophus virgo, Bent-wing (Miniopterus) and Myotis bat species, and at least one other horseshoe (Rhinolophus) bat species. Ten of the caves were confirmed to support multiple bat species. A range of human activities were observed at a number of caves.

Cave locations are shown in Fig. 2. Summary information for each cave is provided in Table 1, with the bat observations further summarised by species in Table 2. Detailed cave descriptions and individual species accounts are provided below, with cave illustrations and photographs provided in Appendices $1-18$.

\section{Cave Descriptions}

In the following accounts, the physical structure and setting of each cave is described, along with any observations or reports of current or historic human activities. This information is summarised in Table 1. Names in brackets refer to local municipalities and provinces. 'Barangay' refers to an administrative division within a municipality (effectively a village), and 'sitio' refers to a further sub-division that is sometimes recognised (particularly in rural areas or for discreet settlements located some distance from a barangay centre).

Cave 1 (Buruanga, Aklan) (Appendix 1): A small, remote limestone cave on a steep forested slope along the uninhabited western coast of the Northwest Panay Peninsula. There are two entrances in the main upper cavern, opposite each other, producing a relatively well-lit interior. In the centre of the cavern is a pillar, beyond which the floor slopes down steeply into two short chambers, one of which is blind-ending, the other opening out into a lower level entrance. The main cavern is approx $5 \mathrm{~m}$ across and $12 \mathrm{~m}$ deep, with a ceiling height of approx $20 \mathrm{~m}$ from the floor of the lower chambers. There appears to be little disturbance, although the cave is known by local fishermen who frequent the nearby coastline, and youths coming from the nearest barangay (graffiti is present inside the cave).

Caves 2 and 3 (Libertad, Antique) (Appendix 2 \& 3): Small limestone caves (approx $4 \mathrm{~m}$ high and $8 \mathrm{~m}$ deep) in close proximity, each consisting of a single entrance and cavern. They are located on the edge of mixed plantation and secondary forest, close to the local sitio, and are frequently visited. Cave 3 showed obvious signs of recent disturbance, with the bottom of the cavern having been repeatedly dug up by a treasure hunter.

Cave 4 (Libertad, Antique) (Appendix 4): A large, remote limestone cave located in the interior of the peninsula, within mixed plantation and secondary forest. There is a large $7 \mathrm{~m}$ vertical slit in a limestone face, leading into the main, approx $15 \mathrm{~m}$ high cavern. Two side branches lead off from this-one relatively short (approx 15m) to the right, and a longer one to the left (not fully explored). The bottom of the main cavern narrows into a small chamber and at the base of this there is running water (not explored). The cave is known to the nearby sitio and has been harvested for fruit bats historically, although this has ceased for the last two years.

Cave 5 (Libertad, Antique) (Appendix 5): Located close to Cave 4, this is a low-ceilinged, shallowsloping limestone tunnel (approx 50m long), open at both ends. The combination of stalactites/stalagmites and small dimensions makes passage through the tunnel quite difficult in several places. The tunnel has only recently been discovered by the local sitio.

Cave 6 (Libertad, Antique) (Appendix 6): A large complex limestone cave system located in the interior of the peninsula, within secondary forest. There is a sink hole sloping down to a large cave entrance and a steeply sloping, $30 \mathrm{~m}$ long outer chamber. At the back 
right corner the ceiling slopes down and leads into a very low narrow passage full of stalactites/stalagmites which has to be crawled through. Part of this passage also has a shallow water pool in it. The passage comes out as a tight opening into a larger, perpendicular tunnel with a stream running along it. Turning right, this passage runs for approx $30 \mathrm{~m}$ until it comes to a dead end, although there are several small blind-ending chambers/tunnels leading off. Turning left the tunnel runs for at least $30 \mathrm{~m}$ until the ceiling becomes very low and further crawling is required (this direction wasn't explored any further). Coming off this section of tunnel is a passage on the right which rejoins the main tunnel, followed by a longer passage, again on the right, which slopes up and runs for approx $30 \mathrm{~m}$. Following this, it then opens up into a wider passage on the left, which in turn opens out into three large caverns (each between $15-20 \mathrm{~m}$ deep by $15 \mathrm{~m}$ high). The third cavern was not fully explored, and this could lead onto further caverns/tunnels. The local barangay are aware of the cave, but it is difficult to get into and appears to have been left undisturbed.

Cave 7 (Libertad, Antique) (Appendix 7): A wellknown cave located in a river valley within secondary forest, accessed from the nearby barangay via an easy walk along a well-used river trail. A short tunnel entrance leads into a large single cavern (approx. $25 \mathrm{~m}$ high) with one upward-sloping side chamber near the entrance and a large cavity high up in the right hand side wall and roof at the back. There is lots of disturbance from frequent visits by local people and occasional foreign tourists. For example, the municipal environment officer mentioned a recent visit by around 800 girl guides, all in the main cavern at the same time. Apparently, coconut leaves are frequently lit inside the cave to illuminate the ceiling of the cavern for visitors.

Cave 8 (Libertad, Antique) (Appendix 8): A confined limestone tunnel with a concealed entrance in a vegetated slope along the same river valley as Cave 7. Approximately $50 \mathrm{~m}$ into the tunnel, there is a water pool spanning its entire width. Passage beyond this point proved difficult because the ceiling gets very low and the floor of the pool is soft and muddy (up to shin deep), so the majority of the tunnel was unexplored. According to our guides the tunnel eventually comes out at another entrance in a neighbouring barangay, and local children are known to explore and play throughout it.

Cave 9 (Libertad, Antique) (Appendix 9): Another well-known, easily accessed limestone cave consisting of three low-ceilinged caverns, located within the same river valley as Caves 7 and 8 . The outer cavern (approx. $20 \mathrm{~m}$ wide $\mathrm{x} 10 \mathrm{~m}$ long $\mathrm{x} 5 \mathrm{~m}$ high) is open-mouthed and very light. It is used by the local barangay as a regular venue for mat-weaving activities and therefore receives regular heavy disturbance. A small constriction at the back of the outer chamber leads into a second slightly larger, dark cavern, which in turn leads into a narrower $15 \mathrm{~m}$ long chamber. These adjoining caverns are less disturbed.

Caves 10-13 (Libertad, Antique) (Appendix 1011): Limestone caves within a private coastal property originally planned for a hotel development, but now kept as a garden with minimal management. Cave 10 (Appendix 10) is a coastal cavern with a wide open mouth, and is only accessible by land at low tide. There is an adjacent smaller coastal cavern (Cave 11) that is accessible at all tides, with no sign of bats recorded. Cave 12 (Appendix 11) is within the garden itself and has a small, partially collapsed entrance with a $10 \mathrm{~m}$ vertical drop leading into small, sloped cavern, approx $7 \mathrm{~m}$ deep. There is another smaller vertical cave within the garden (Cave 13), again with no sign of bats recorded. There is currently little/no disturbance to any of the caves.

Cave 14 (Libertad, Antique) (Appendix 12): A small, shallow limestone cave $(<5 \mathrm{~m}$ deep) on the edge of a pool and waterfalls forming part of a river. The base of the cave is filled with water to a depth of approx $0.5 \mathrm{~m}$. The cave is a $2 \mathrm{hr}$ walk from the nearest barangay, along a reasonably difficult route upstream into hilly primary and secondary forest. However, the river, waterfalls and pools are a local tourist destination (although probably not often visited) and are well used by the locals for fishing and recreation; groups of youths and children were seen fishing and playing in the waters, and it is likely that children play within the cave.

Cave 15 (Libertad, Antique) (Appendix 13): A large, steep (vertical in several places) tunnel-like limestone cave with intact stalactite formations. The explored section of cave was at least $75 \mathrm{~m}$ long, and comprised three distinct chambers. This is a remote cave located on private property in the hilly interior of the peninsula, within mixed plantation and secondary 
Table 1. Summary of cave descriptions, including bat species observations and known threats

\begin{tabular}{|c|c|c|c|c|}
\hline $\begin{array}{l}\text { Cave } \\
\text { No. }\end{array}$ & Description & Species & $\begin{array}{l}\text { Estimated } \\
\text { numbers }\end{array}$ & Known threats/other notes \\
\hline 1 & $\begin{array}{l}\text { Limestone cave within coastal secondary } \\
\text { forest }\end{array}$ & $\begin{array}{l}\text { E. alecto } \\
R . \text { virgo }\end{array}$ & $\begin{array}{l}3 \\
1\end{array}$ & $\begin{array}{l}\text { Little disturbance, although known by local } \\
\text { fishermen and nearest barangay e.g., graffiti } \\
\text { present }\end{array}$ \\
\hline 2 & $\begin{array}{l}\text { Small limestone cave on edge of } \\
\text { secondary forest/plantation }\end{array}$ & Droppings only & - & Frequent disturbance from local sitio \\
\hline 3 & $\begin{array}{l}\text { Small limestone cave on edge of } \\
\text { secondary forest/plantation }\end{array}$ & Droppings only & - & Frequent disturbance from treasure-hunting \\
\hline 4 & $\begin{array}{l}\text { Limestone cave within mixed plantation } \\
\text { and secondary forest }\end{array}$ & R. amplexicaudatus ${ }^{1}$ & $6,500-8,000$ & $\begin{array}{l}\text { Remote but historically bats have been } \\
\text { harvested by local sitio; emergence survey } \\
\text { undertaken }\end{array}$ \\
\hline 5 & $\begin{array}{l}\text { Low-ceilinged, shallow-sloping limestone } \\
\text { tunnel, open at both ends, within } \\
\text { secondary forest }\end{array}$ & $\begin{array}{l}\text { M. spasma } \\
\text { Rhinolophus sp. }\end{array}$ & $\begin{array}{l}1 \\
1\end{array}$ & $\begin{array}{l}\text { Little disturbance - only just discovered by local } \\
\text { sitio }\end{array}$ \\
\hline 6 & $\begin{array}{l}\text { Large complex limestone cave system } \\
\text { within secondary forest }\end{array}$ & $\begin{array}{l}\text { H. ater }{ }^{1} \\
R . \text { arcuatus } \\
\text { Microbat sp. }\end{array}$ & $\begin{array}{l}\text { Mixed colony } \\
\text { of several } \\
\text { thousand bats, } \\
\text { predominantly } \\
\text { H. ater }\end{array}$ & $\begin{array}{l}\text { Little disturbance, although known to local } \\
\text { barangay; only partially explored }\end{array}$ \\
\hline 7 & $\begin{array}{l}\text { Large limestone cavern within forested } \\
\text { river valley }\end{array}$ & $\begin{array}{l}\text { R. amplexicaudatus }{ }^{1} \\
\text { Rhinolophus sp. } \\
\text { Microbat sp. } \\
2^{\text {nd }}{\text { Fruit bat } s p ?^{3}}^{3}\end{array}$ & $\begin{array}{l}3,400 \\
15 \\
10 \\
\sim 5\end{array}$ & $\begin{array}{l}\text { Well known with frequent disturbance; } \\
\text { emergence survey undertaken }\end{array}$ \\
\hline 8 & $\begin{array}{l}\text { Confined limestone tunnel within forested } \\
\text { river valley }\end{array}$ & Rhinolophus sp. & 3 & $\begin{array}{l}\text { Little disturbance, although known to local } \\
\text { barangay; only partially explored }\end{array}$ \\
\hline 9 & $\begin{array}{l}\text { Wide, low-ceilinged limestone cave within } \\
\text { forested river valley }\end{array}$ & $\begin{array}{l}\text { Rhinolophus sp. } \\
\text { M. spasma } \\
\text { C. brachyotis }\end{array}$ & $\begin{array}{l}3 \\
2 \\
1\end{array}$ & Well known with frequent disturbance \\
\hline 10 & $\begin{array}{l}\text { Coastal limestone cave only accessible } \\
\text { at low tide }\end{array}$ & $\begin{array}{l}\text { E. alecto } \\
\text { M. spasma }\end{array}$ & $\begin{array}{l}5 \\
2\end{array}$ & \multirow{4}{*}{$\begin{array}{l}\text { Within private property - little/no disturbance, } \\
\text { although the site has previously been ear- } \\
\text { marked for hotel development }\end{array}$} \\
\hline 11 & Coastal limestone cave & \multicolumn{2}{|c|}{ No Evidence of bats found } & \\
\hline 12 & $\begin{array}{l}\text { Small vertical limestone cave in disused } \\
\text { garden }\end{array}$ & M. spasma ${ }^{2}$ & 15 & \\
\hline 13 & Small limestone cave in disused garden & \multicolumn{2}{|c|}{ No Evidence of bats found } & \\
\hline 14 & $\begin{array}{l}\text { A small, shallow limestone river cave } \\
\text { within primary forest }\end{array}$ & $\begin{array}{l}\text { Myotis sp. } \\
\text { Miniopterus sp. }\end{array}$ & $\begin{array}{l}5 \\
4\end{array}$ & $\begin{array}{l}\text { Disturbance likely - area well used by locals for } \\
\text { fishing and recreation }\end{array}$ \\
\hline 15 & $\begin{array}{l}\text { Large, steep, tunnel-like limestone cave } \\
\text { within mixed plantation and secondary } \\
\text { forest }\end{array}$ & $\begin{array}{l}\text { H. diadema }{ }^{2} \\
\text { C. brachyotis } \\
\text { E. alecto }\end{array}$ & $\begin{array}{l}>35 \\
2 \\
2\end{array}$ & $\begin{array}{l}\text { Within private property - little/no disturbance; } \\
\text { only partially explored }\end{array}$ \\
\hline 16 & $\begin{array}{l}\text { Large limestone complex located deep } \\
\text { within primary forest of Central Panay } \\
\text { Mountain Range }\end{array}$ & R. amplexicaudatus ${ }^{1}$ & 198,000 & $\begin{array}{l}\text { Little disturbance; however harvesting does } \\
\text { occur and local guides believe this has } \\
\text { increased in recent years; only partially explored; } \\
\text { emergence survey undertaken but not all cave } \\
\text { entrances covered }\end{array}$ \\
\hline 17 & $\begin{array}{l}\text { Limestone cave within secondary forest } \\
\text { on the edge of agriculture }\end{array}$ & C. brachyotis & 5 & Some disturbance e.g., graffiti present \\
\hline 18 & $\begin{array}{l}\text { Vertical fissure in limestone cliff face of } \\
\text { small rocky island }\end{array}$ & $\begin{array}{l}\text { T. melanopogon }{ }^{2} \\
\text { Microbat sp. }\end{array}$ & $\begin{array}{l}\sim 50 \\
1\end{array}$ & Little/no disturbance \\
\hline 19 & $\begin{array}{l}\text { Vertical fissure in limestone cliff face of } \\
\text { small rocky island }\end{array}$ & T. melanopogon & 3 & Little/no disturbance \\
\hline 20 & $\begin{array}{l}\text { Small limestone cave system with seven } \\
\text { inter-connected caverns, on edge of } \\
\text { primary forest }\end{array}$ & $\begin{array}{l}\text { H. ater } \\
\text { M. spasma }\end{array}$ & $\begin{array}{l}\sim 200 \\
8\end{array}$ & $\begin{array}{l}\text { Overall little disturbance, although occasionally } \\
\text { used by local barangay e.g., small amount of } \\
\text { graffiti present }\end{array}$ \\
\hline 21 & Limestone cave on edge of primary forest & Microbat sp. & 1 & $\begin{array}{l}\text { Some disturbance from local barangay e.g. } \\
\text { graffiti present }\end{array}$ \\
\hline
\end{tabular}

${ }^{1}$ Confirmed maternity roost; ${ }^{2}$ Potential maternity roost, not confirmed; ${ }^{3}$ A possible $2{ }^{\text {nd }}$ fruit bat species was observed but not confirmed 
Table 2. Summary of bat species recorded within each cave where evidence of bats was found

\begin{tabular}{|c|c|c|c|c|c|c|c|c|c|c|c|c|c|c|c|c|c|c|c|}
\hline \multirow{2}{*}{ Species } & \multicolumn{19}{|c|}{ Cave No } \\
\hline & 1 & 2 & 3 & 4 & 5 & 6 & 7 & 8 & 9 & 10 & 12 & 14 & 15 & 16 & 17 & 18 & 19 & 20 & 21 \\
\hline $\begin{array}{l}\text { Rousettus } \\
\text { amplexicaudatus }\end{array}$ & & & & $X^{1}$ & & & $\mathrm{X}^{1}$ & & & & & & & $X^{1}$ & & & & & \\
\hline Cynopterus brachyotis & & & & & & & & & $x$ & & & & $\mathrm{x}$ & & $x$ & & & & \\
\hline Taphozous melanopogon & & & & & & & & & & & & & & & & $x^{2}$ & $\mathrm{X}$ & & \\
\hline Emballonura alecto & $\mathrm{x}$ & & & & & & & & & $x$ & & & $\mathrm{x}$ & & & & & & \\
\hline Megaderma spasma & & & & & $x$ & & & & $x$ & $x$ & $\mathrm{X}^{2}$ & & & & & & & $x$ & \\
\hline Hipposideros ater & & & & & & $X^{1}$ & & & & & & & & & & & & $X^{1}$ & \\
\hline Hipposideros diadema & & & & & & & & & & & & & $x^{2}$ & & & & & & \\
\hline Rhinolophus arcuatus & & & & & & $x$ & & & & & & & & & & & & & \\
\hline Rhinolophus virgo & $x$ & & & & & & & & & & & & & & & & & & \\
\hline Rhinolophus sp. & & & & & $x$ & & $x$ & $x$ & $x$ & & & & & & & & & & \\
\hline Myotis sp. & & & & & & & & & & & & $x$ & & & & & & & \\
\hline Miniopterus sp. & & & & & & & & & & & & $x$ & & & & & & & \\
\hline Microbat sp. & & $X^{3}$ & $X^{3}$ & & & $x$ & $x$ & & & & & & & & & $\mathrm{X}$ & & & $x$ \\
\hline Fruit bat sp. & & & & & & & $?^{4}$ & & & & & & & & & & & & \\
\hline
\end{tabular}

${ }^{1}$ Confirmed maternity roost; ${ }^{2}$ Potential maternity roost, not confirmed; ${ }^{3}$ Bat guano only; ${ }^{4}$ A possible $2{ }^{\text {nd }}$ fruit bat species was observed but not confirmed

forest. It is difficult to find and get into and currently appears to receive little/no disturbance.

Cave 16 (Ibajay, Aklan) (Appendix 14): A very remote limestone cave system accessed via a $3-5 \mathrm{hr}$ easy walk up river to Yawan barangay, followed by a 5-7hr difficult river/mountain trek into the primary forests of the Central Panay Mountain Range. There is a crater (approx. 15m long and deep), leading on one side into (16a) - an open cavern (with a ceiling height of approx. $15 \mathrm{~m}$ ), at the far end of which is a big opening in the ceiling (effectively the cavern is an extension of the crater, with a land bridge over the top). On the other side of the crater there is (16b) - a large cave entrance ( $10 \mathrm{~m}$ across by $5 \mathrm{~m}$ high) leading into two big closed chambers of approx. 30m length, one sloping upwards, the other downwards. A short distance from the crater complex there is (16c)-another small cave entrance ( $2 \mathrm{~m}$ across by $3 \mathrm{~m}$ high) leading into a separate, smaller cavern (this was not explored and it is not known whether it connects with the main cave system). Intact stalactites and stalagmites are present throughout the system. Due to its remote location there is little disturbance to the cave system. However, bat-harvesting does occur here, and according to the Yawan locals, despite the difficult journey a hunter can take a $30 \mathrm{~kg}$ sack of bats in one trip. The locals also believe that recently there has been an increase in harvesting, due to hunters from barangays on the other side of the mountain range discovering the cave.

Cave 17 (Sebaste, Antique) (Appendix 15): A large, single, well-lit limestone cavern (approx $15 \mathrm{~m}$ deep by $15 \mathrm{~m}$ high) with two entrances, one at ground level and one high up in the ceiling. The cave is located in secondary forest/scrub on the edge of rice fields. Nearby is a locally well-known camp of flying foxes (these have previously been identified as Pteropus hypomelanus - R. Galang pers. comm. 12 April 2011) which is visible from the main provincial road into Culasi. The cave appears to be known locally and is probably used by youths (graffiti is present).

Cave 18 (Appendix 16) and 19 (Culasi, Antique): Vertical fissures in the south and north cliff faces of a small rocky island to the west of Malalison Island. Cave 18 is approx $5 \mathrm{~m}$ deep by $20 \mathrm{~m}$ high, and towards the back a beach rises from the sea, leading to a slightly deeper, $2 \mathrm{~m}$ high recess at the base of the back wall. In the roof of this recess there are lots of cracks and crevices. Cave 19 is a generally smaller fissure than Cave 18, but at the back/bottom of it there is a hole in the cliff leading into a small sea cavern (approx. $5 \mathrm{~m}$ wide $\mathrm{x} 5 \mathrm{~m}$ deep $\times 3 \mathrm{~m}$ high). These sites are not accessible by land and as a result receive little/no 
disturbance.

Cave 20 (Barbaza, Antique) (Appendix 17): A small entrance hole in a well-vegetated, rocky limestone hill, with a short $5 \mathrm{~m}$ vertical drop leading down into a sloping cave consisting of seven interconnected caverns. The largest cavern was approx $8 \mathrm{~m}$ across by $5 \mathrm{~m}$ deep by $4 \mathrm{~m}$ high. Although the general area is limestone, the inside of the cave has a very smooth floor. The cave is known by the local barangay and receives occasional visits from youths (graffiti is present on the walls). However, our guides had difficulty finding the cave and said they weren't aware that anyone had visited it during the last two years.

Cave 21 (Barbaza, Antique) (Appendix 18): A 10m long tunnel in a well-vegetated, rocky limestone hill, leading into a more open, $15 \mathrm{~m}$ high-ceilinged cavern at the back. There were several smaller chambers leading off from this cavern, but these were high up and not easily accessible. The cave is known by the local barangay and more frequently visited than nearby Cave 20 (there is more extensive graffiti present on the walls). However, our guides still had difficulty finding the cave.

\section{Species Accounts}

The following detailed species accounts are summarised by cave in Table 1, and by species in Table 2. Echolocation calls were recorded in four caves to further aid identification of the bat species present the results are summarised in Table 3 and discussed further in the relevant species accounts, with example sonograms provided in Figs. 3-6.

\section{Pteropodidae}

Rousettus amplexicaudatus: Three large maternity roosts were observed in Caves 4, 7 and 16. At the entrance to Cave 4 there were obvious fruit bat smell and sounds, and as we entered the cave, large numbers of bats were seen in the main cavern. Smaller individuals (juveniles) were observed, and one photo taken inside the cave clearly shows an adult in flight carrying a well-developed young. The bats were easily disturbed (presumably due to historic harvesting) and the majority flew into the longer side branch on the left. An emergence survey provided a population estimate of 6,500 (actual count) - 8,000 (based on emergence rates) individuals. At Cave 7 large numbers of this species were observed roosting in the cavity high up in the right hand side wall and roof at the back of the main cavern. A scattering of individuals were also observed high up on the ceiling of the main cavern itself, although these could have been a different fruit bat species. An emergence survey at the cave provided a population estimate of 3,400 individuals (actual count). At Cave 16 a mass of bats was observed on the ceiling of the land bridge (16a), with lots of flight activity in the twilight zone beneath. There was a layer of guano in this area, at least ankle deep. In the cave opposite (16b) huge numbers of bats were again present, on the ceiling of the upper cavern, with corresponding amounts of guano. Bats were also observed in the lower cavern, but in far fewer numbers. At the nearby smaller cave (16c) there was lots of noise coming from inside and numerous bats were seen flying past the entrance, including adult females with young attached. A partial emergence survey of one side of the land bridge and the main cave entrance provided a population estimate of 198,000 individuals (based on emergence rates). Observer locations and views during this emergence survey are shown in Appendix 14.

Cynopterus brachyotis: Small numbers of individuals were observed in Caves 9, 15 and 17. At Cave 9 a single bat was recorded hanging from the ceiling in the dark zone. At Cave 15 two bats were seen in a roof crevice next to a stalactite in the twilight zone. At Cave 17 five bats were disturbed from the ceiling in the twilight zone near the cave entrance, which flew around and eventually settled part way up the back wall of the cave.

\section{Fruit Bat sp.}

At Cave 7 approximately five fruit bats were observed high above, scattered across the ceiling of the main cavern, separate from the large roost of $R$. amplexicaudatus. It was not possible to confirm whether these were also $R$. amplexicaudatus or a different fruit bat species.

\section{Emballonuridae}

Taphozous melanopogon: A colony of approximately 50 bats was observed in the light zone, hanging free from the walls of a south-facing sea cliff fissure (Cave 18). They were easily disturbed - several flew out into the open, while the rest flew into the 
recess at the back of the fissure and crawled up into cracks and crevices in the recess ceiling. Three bats were subsequently observed hanging free from the walls of another fissure on a north-facing cliff (Cave 19), and presumably these were bats that had been disturbed from Cave 18.

Emballonura alecto: Small numbers of individuals were observed in Caves 1,10 and 15. At Cave 1 three bats were observed hanging free on the wall at the back of the upper cavern in the twilight zone. They were easily disturbed, continually flying around, although they didn't leave the cave. At Cave 10 five bats were seen hanging free on a wall in the twilight zone near the cave entrance, subsequently crawling backwards into crevices upon disturbance. At Cave 15 two bats were seen hanging free on a wall in the twilight zone of the outermost chamber.

\section{Megadermatidae}

Megaderma spasma: With records from five caves (Caves 5, 9, 10, 12 and 20), this was the most frequently encountered species. A small colony of 15 bats was observed in Cave 12, with animals hanging individually and in small clusters from the ceiling at the back of the cavern in the dark zone. A further two bats were observed on the ceiling in the dark zone of the nearby Cave 10. At Cave 9 two individuals were seen hanging together from the ceiling of the second cavern, and at Cave 20 a colony of eight bats was observed in the deepest cavern of the system. At Cave 5 a partially decomposed corpse was found on the floor of the tunnel (skull measurements: condylocanine length $=22.5 \mathrm{~mm}$, maxillary toothrow $=9 \mathrm{~mm}$; body measurements: hind foot $=8 \mathrm{~mm}$, forearm $=59 \mathrm{~mm}$ ).

\section{Hipposideridae}

Hipposideros ater: Two large maternity roosts were observed in Caves 6 and 20. At Cave 6 a large colony of bats, potentially numbering in the thousands, was observed in the three caverns located furthest into the cave system. Individuals were seen hanging free from the ceilings and walls, and a mother with a blind, naked pup was observed. There was a significant quantity of guano (covering the ground of all the caverns, ankle deep in places), and a noticeable smell. The bats were easily disturbed, and subsequently encountered flying along the entire length of the cave system, all the way to the outer chamber. The colony comprised at least three species (Rhinolophus arcuatus and a microbat sp. were also observed), and only a rough estimate of numbers could be made on the single visit undertaken as part of the present study. Nevertheless, H. ater was the predominant species observed, and an impression of the quantity of bats encountered, together with the extent of guano and the fact that the large maternity roost caverns were not fully explored suggests that numbers in the cave system could be in the thousands. At Cave 20 individual bats were seen flying around and hanging on the walls of the outer caverns, and the main roost area was located in the fourth cavern, with approximately 200 bats seen hanging from the ceiling and flying around. A very young juvenile (naked and blind, with just a hint of fur coming through) was observed hanging from the ceiling, confirming that this is a maternity site. The bats appeared very sensitive to disturbance.

Hipposideros diadema: At least 35 bats, in groups of five, 10 and 20, were observed hanging free on walls in the dark zone of the explored chambers of Cave 15. Echolocation calls were detected further beyond, indicating that more bats were present,

Table 3. Summary of echolocation call data with calls embeded as audio files

\begin{tabular}{|c|c|c|c|c|c|}
\hline Cave No. & Species & $\begin{array}{l}\text { Mean Call frequency } \pm \\
\text { Standard Error }(\mathrm{kHz})\end{array}$ & $\begin{array}{l}\text { Call Range }{ }^{1} \\
(\mathrm{kHz})\end{array}$ & Audio files & Sonogram \\
\hline \multirow{3}{*}{7} & \multirow{3}{*}{$\begin{array}{l}\text { Rhinolophus sp. (such as } \\
\text { philippinensis \& virgo?) }\end{array}$} & $34.2 \pm 0.1$ & $33.4-34.9(76)$ & \multirow{3}{*}{ Audio 1} & \multirow{3}{*}{ Fig. 3} \\
\hline & & $39.4 \pm 0.1$ & $38.8-40.2(53)$ & & \\
\hline & & $89.0 \pm 0.1$ & $88.7-90.1(57)$ & & \\
\hline 8 & Rhinolophus sp. (arcuatus?) & $69.2 \pm 0.1$ & $68.3-69.3(10)$ & Audio 2 & Fig. 4 \\
\hline 9 & Rhinolophus sp. (virgo?) & $83.2 \pm 0.3$ & $82.4-84.8(12)$ & Audio 3 & Fig. 5 \\
\hline 13 & Hipposideros diadema & $69.4 \pm 0.1$ & $66.9-70.8(164)$ & Audio 4 & Fig. 6 \\
\hline
\end{tabular}

${ }^{1}$ Figures in brackets indicate the sample size (number of individual calls analysed within a recorded echolocation call sequence) 


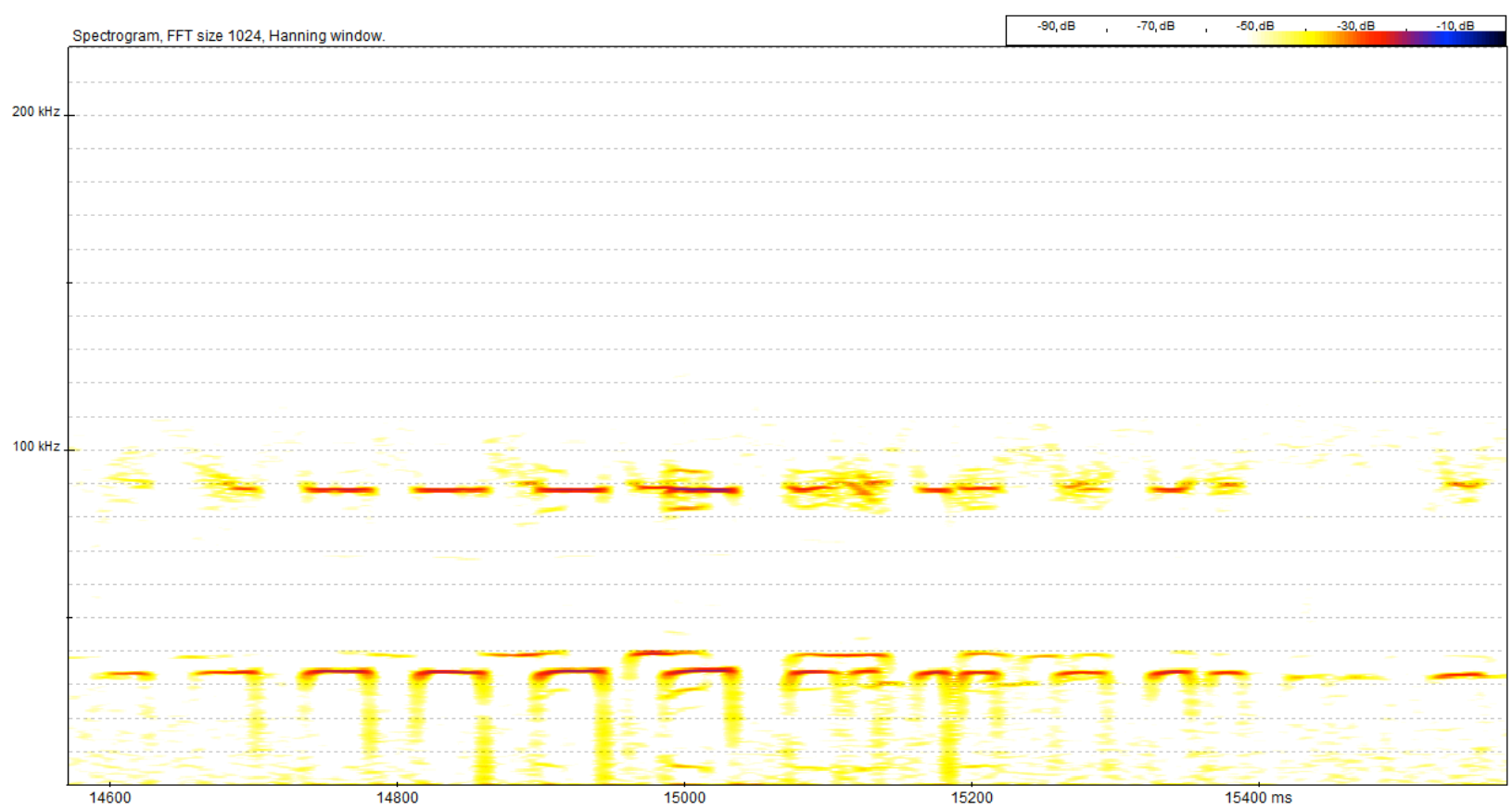

Figure 3. Rhinolophus sp. (Cave 7)

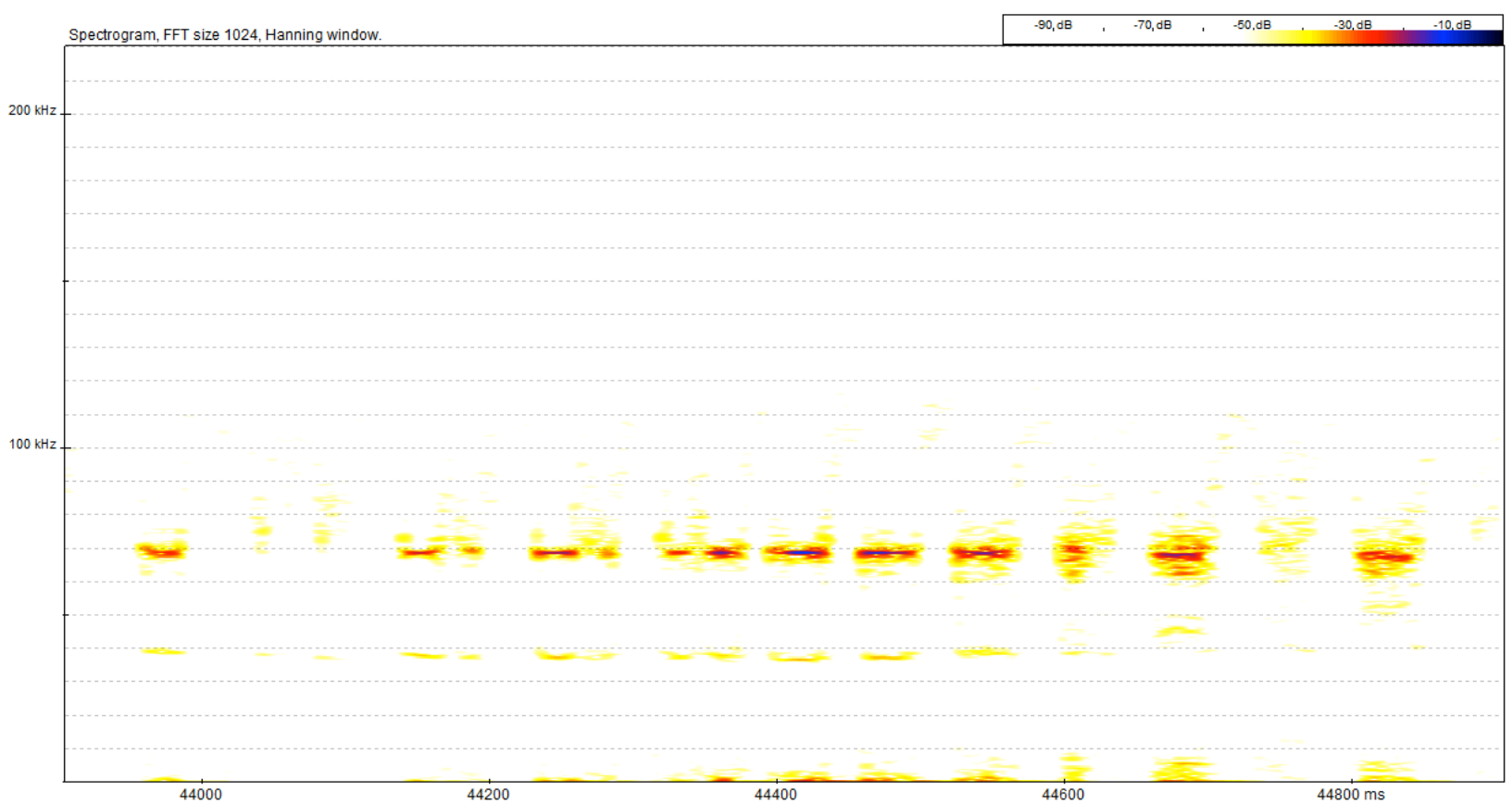

Figure 4. Rhinolophus sp. (Cave 8)

but deeper exploration into the cave was not made. Given the size of the cave, the lack of disturbance and the intensity of echolocation calls recorded, there is potential for a large colony of bats to be present. This species was recorded using constant frequency/ frequency modulation ( $\mathrm{CF} / \mathrm{FM})$ calls with a mean $\mathrm{CF}$ component of $69.4 \mathrm{kHz}$. This is slightly higher than the mean call frequency of $67 \mathrm{kHz}$ recorded for this species elsewhere in the Philippines within central Luzon (Sedlock 2001). However there is good overlap between the ranges of call frequencies recorded from the two areas. 


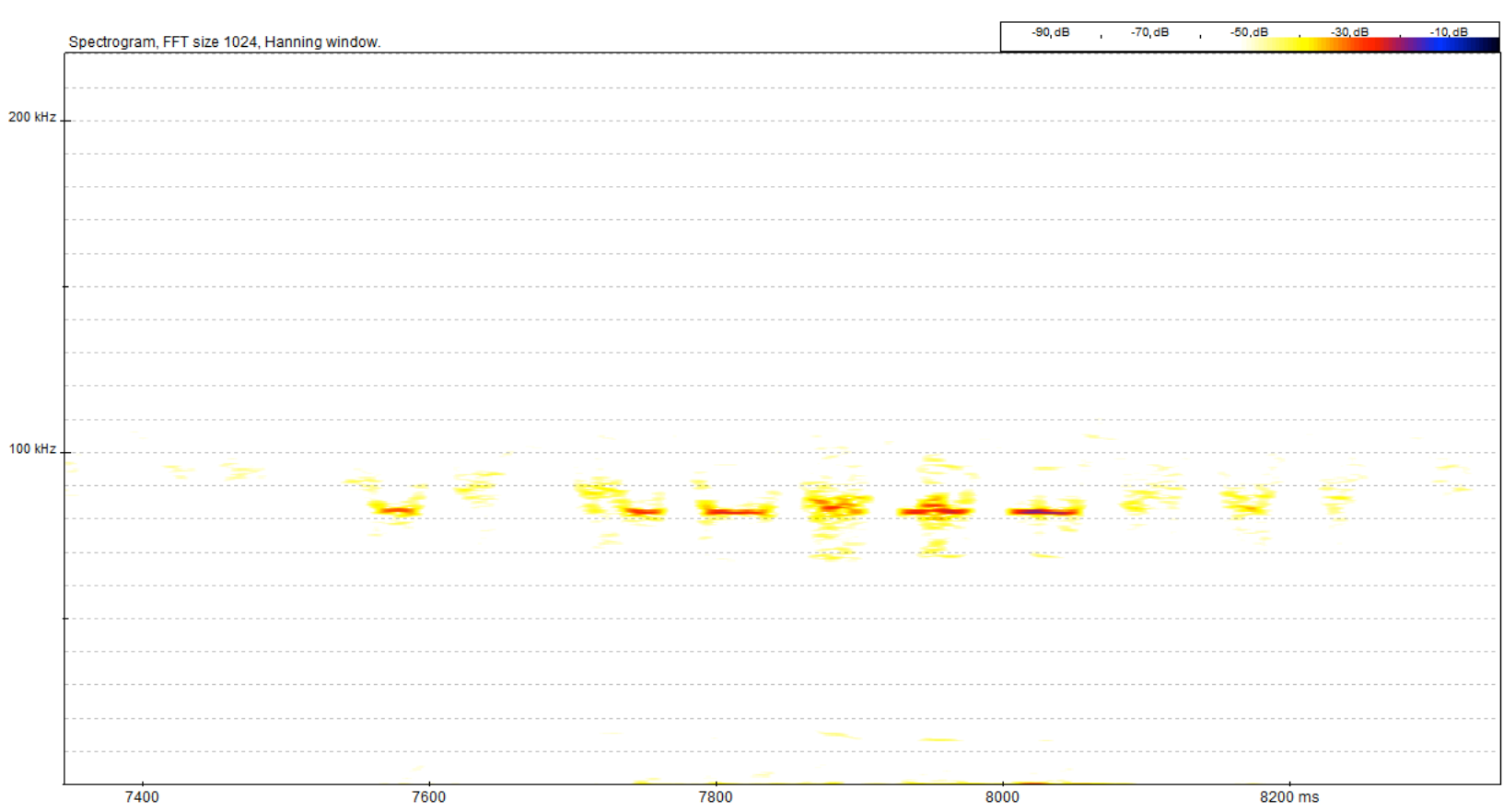

Figure 5. Rhinolophus sp. (Cave 9)

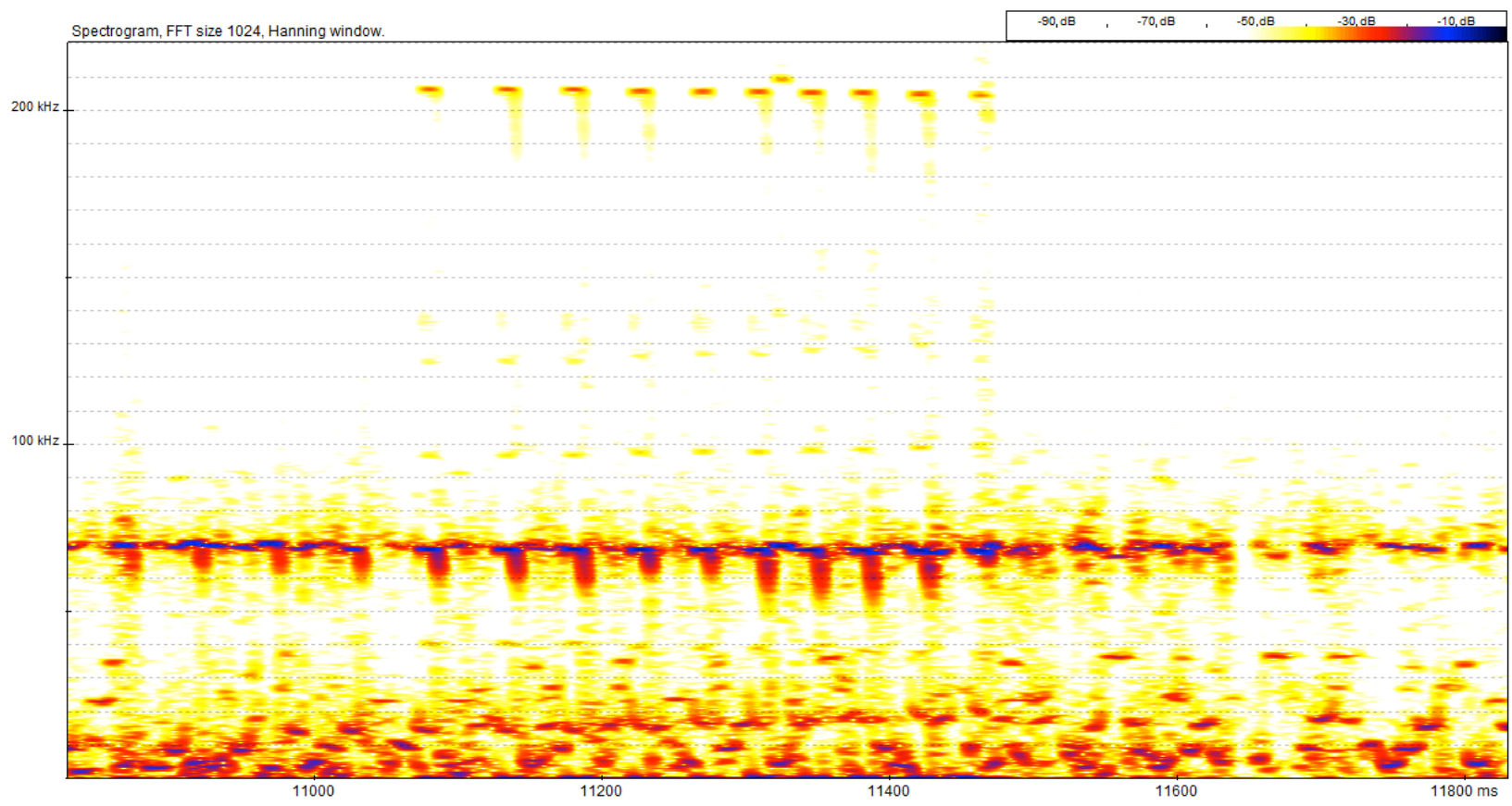

Figure 6. Hipposideros diadema (Cave 13)

\section{Rhinolophidae}

Rhinolophus arcuatus: Individual horseshoe bats were noted in the first large cavern of Cave 6, including a recently deceased animal hanging free from a wall. The specimen was collected and subsequently identified as $R$. arcuatus (body measurements: total length $=68 \mathrm{~mm}$, tail $=17 \mathrm{~mm}$, hind foot $=11 \mathrm{~mm}$, ear $=$
$18 \mathrm{~mm}$, forearm $=47 \mathrm{~mm}$, weight $=9 \mathrm{~g}$ ).

Rhinolophus virgo: At Cave 1 a single bat was seen hanging free near the passage down to the lower chamber. Upon discovery it flew into the adjacent blind chamber, and then back again, before exiting the cave via the lower entrance.

Rhinolophus sp.: Unconfirmed horseshoe bat 
species were observed at Caves 5, 7,8 and 9. At Cave 5 a single horseshoe bat was briefly seen hanging from a wall, flying off into the surrounding forest upon disturbance. At Cave 7 a small colony of approximately 15 horseshoe bats were observed. An analysis of the calls recorded from this group indicates that two distinct $\mathrm{FM} / \mathrm{CF} / \mathrm{FM}$ calls were being used, with the mean $\mathrm{CF}$ components occurring at $34.2 \mathrm{kHz}$ and $39.4 \mathrm{kHz}$. In addition, separate CF calls with a mean frequency of $89.0 \mathrm{kHz}$ were also recorded. The 34 and $39 \mathrm{kHz}$ recordings most likely represent natural variation between calls in the same species, and although there are no published accounts of horseshoe bat calls occurring at this range of frequencies within the Philippines, calls between $30-33 \mathrm{kHz}$ have been recorded from the Enormous-eared Horseshoe Bat R. philippinensis on Bohol Island (J. Sedlock pers. comm. 03 November 2011). Fewer 89 kHz calls were recorded, but when they did occur the timing was always perfectly matched with one of the lower frequency calls. These recordings may therefore simply represent additional harmonic components of the lower frequency calls. Alternatively, they could represent separate calls from a different species, such as $R$. virgo - in central Luzon, calls from this species have been recorded between $83-88 \mathrm{kHz}$ (Sedlock 2001). At Cave 8 a small group of three horseshoe bats was observed, from which short CF calls with a mean frequency of $69.2 \mathrm{kHz}$ were recorded. In central Luzon calls from $R$. arcuatus have been recorded between $67-72 \mathrm{kHz}$ (Sedlock 2001), suggesting that the bats observed in this cave may have been that species. At Cave 9 a small group of three horseshoe bats was observed, from which short CF calls with a mean frequency of $83.2 \mathrm{kHz}$ were recorded, suggesting they were $R$. virgo (again compared with calls recorded by Sedlock 2001).

Based on the above it is concluded that during the present study at least three horseshoe species were encountered - $R$. virgo (visually confirmed in Cave 1 and potentially accounting for the $83-89 \mathrm{kHz}$ calls recorded in Caves 7 and 9) and $R$. arcuatus (visually confirmed in Cave 6 and potentially accounting for the $69 \mathrm{kHz}$ calls recorded in Cave 8), along with a different unconfirmed species (such as $R$. philippinensis) echolocating between $33-40 \mathrm{kHz}$ in Cave 7.

\section{Vespertilionidae}

Myotis sp.: At Cave 14 a group of five bats were observed hanging free on the wall at the cave entrance in direct light. These were either $M$. horsfieldii or $M$. macrotarsus, but without a forearm measurement, species-level identification couldn't be confirmed.

Miniopterus sp.: At Cave 14 four bats were found at the back of the cave in the twilight zone, hanging free and tucked into shallow crevices. Three flew out upon disturbance, but one was still torpid. This individual was carefully examined to confirm the presence of wing characteristics which are diagnostic of this family/genera, although forearm measurements could not be taken to confirm species-level identification.

\section{Microbat sp.}

At Cave 6 a small group of bats (approx 20 individuals) was briefly observed hanging from the entrance into the first large cavern before flying off. Based on the previous encounter with Miniopterus sp. at Cave 14, the general indication of size and shape observed suggested the bats were of that genus; however without any reliable evidence, identification, even to family level, could not be confirmed. At Cave 7 a small clump of bats was observed high up around stalactites in the twilight zone at the tunnel entrance, and a scattering of individuals were also seen high up on the ceiling of the main cavern. At Cave 18 a single individual of another microbat species was seen roosting within a crevice in amongst $T$. melanopogon. From the facial features that could be seen the bat appeared to be a freetail bat (Mollosidae sp.); however the sighting was brief and obscured, and so identification, even to family level, could not be confirmed. At Cave 21 a single microbat was briefly seen flying around inaccessible chambers high up in the main cavern.

Whilst no bats were observed at Caves 2 and 3, fresh piles of bat guano were recorded. Individual droppings crumbled to dust when pinched, revealing insect fragments and confirming that these were from insectivorous bats. 


\section{DISCUSSION}

\section{Species observations}

During the five weeks of surveys, 21 caves were visited across western Panay, of which 17 were confirmed to have bats present and a further two showed evidence of recent occupancy. Of the species confirmed, all were previously known to occur on Panay Island (see Heaney et al. 2010), and many of the observations reflect existing knowledge of species status and distribution across the Philippines and wider South-east Asia (Csorba et al. 2008; Heaney et al. 2010). However, significant findings during the study included newly documented maternity roosting sites of conservation importance for $R$. amplexicaudatus and $H$. ater, confirmation of cave-roosting behaviour on the island for $C$. brachyotis, and observations of $M$. spasma co-habiting with a range of other bat species. Further detailed discussions of these findings are provided below.

Rousettus amplexicaudatus: This is a locally abundant species across South-east Asia and the Philippines (Csorba et al. 2008), most commonly occurring within agricultural and residential land, rarely found in forest, and known to roost in large groups of up to 100,000 individuals (Heaney et al. 2010). On Negros Island, the species has been found to have two birth periods in each year, centred on March or April and August or September (Heideman \& Utzurrum 2003). The observations at Caves 4 and 7 in Libertad (colonies of $<10,000$ bats, with young present during April 2011, located in secondary forest near to human habitation), while being important, are therefore as typically described for this species. In contrast, the maternity colony observed in Cave 16, also during April, is located deep within the primary forest of the Central Panay Mountain Range and supports at least 198,000 individuals (likely to be an under-estimate given that only a partial emergence survey of the cave system was undertaken). During a previous PSDCF expedition to the cave, another group of volunteers also conducted an emergence survey and estimated the cave population to be 500,000 (R. Galang pers. comm. 24 April 2011). However, there is no record of the methodology used, and based on existing colony descriptions for this species this figure is possibly an over-estimate. An exceptionally large colony of 1.8 million individuals is known for this species in the
Philippines at Monfort Cave in Mindanao, with the size of the colony resulting from bats being forced into the safety of this protected site from surrounding caves through hunting pressure (Locke 2006). Cave 16 nevertheless appears to represent an unusually large colony of $R$. amplexicaudatus, located outside of its typical habitat. The most likely explanation for the location and size of this colony is the relative safety afforded by the remoteness of the cave. While the conservation status of the species is currently of Least Concern (Csorba et al. 2008), it would appear that the importance of the colony in national (if not global) terms, along with the anecdotal reports from local guides of a recent decline in the population due to increased hunting from surrounding barangays, warrants the undertaking of further study and implementation of protective conservation measures.

At all the caves, there was potential for other fruit bat species, such as E. spelaea, to be present within the colonies. However, during emergence surveys, echolocation calls were detected from most bats seen emerging over the entire emergence period, indicating that $R$. amplexicaudatus was the predominant, if not only fruit bat species present.

Hipposideros ater: This is a widespread species occurring from India to Australia (Csorba et al. 2008). It roosts in caves in primary and secondary forest and in agricultural areas, with colony sizes between 300-500 individuals known to occur (Bonaccorso 1998; Churchill 2008; Heaney et al. 2010). In the Philippines, the species is not commonly encountered (Csorba et al. 2008). The timing of reproduction varies geographically - in Australia, pregnant females are pregnant by June, and young are born between October and December (Churchill 2008); in the Philippines, pregnant females have been recorded on Catanduanes Island during February (Heaney et al. 1991) and on Palawan during May (Esselstyn et al. 2004). The observations of very young pups in Caves 6 and 20 during early May suggest that the phenology of $H$. ater on Panay Island is similar to that recorded on Catanduanes Island. The size of the observed colony (approx. 200 bats) in Cave 20 in Barbaza is as typically described, although it would appear to be important in the context of the status of the species in the Philippines. However, the mixedspecies colony of thousands of bats observed in Cave 6 in Libertad, comprising predominantly of $H$. ater, 
appears to represent one of the largest documented for this species. The most likely explanation for the size of the colony is the lack of disturbance due to the difficulty of entering the cave combined with the location of the main caverns, deep inside the complex cave system. While the conservation status of the species is currently of Least Concern (Csorba et al. 2008), it would appear that the importance of the colony in national (if not global) terms, warrants the undertaking of further study and implementation of protective conservation measures.

Cynopterus brachyotis: The taxonomic status of this species is unclear, but it appears to represent a species-complex of six distinct geographical lineages (Campbell et al. 2004). Within the Philippines the complex is represented by an endemic Philippine lineage as well as the more widely distributed Sunda lineage, which in the Philippines only occurs on Palawan (Campbell et al. 2004). It is an abundant species of disturbed lowland habitats, including residential, agricultural, and urban areas (Heaney et al. 2010). It is often found roosting in palm trees, and is known to shelter beneath fronds which have been modified through tent-making behaviour (Tan et al. 1997). According to Esselstyn et al. (2004), the species occasionally roosts in caves in Borneo and Palawan, although this behaviour had not been observed in the endemic lineage of the oceanic Philippines. More recently, small numbers of $C$. brachyotis have been observed roosting in a cave on Danjugan Island, just off the southwest coast of Negros Island (O'Malley et al. 2006). During the present study small numbers $(\leq 5)$ of $C$. brachyotis were confirmed roosting in three caves on Panay Island, in both single and mixed-species colonies. These are the first recorded observations of cave-roosting for this species on Panay Island, providing further evidence that this behaviour occurs in the endemic Philippine lineage, and suggests it is a relatively common occurrence, at least within the Greater Negros-Panay Faunal Region.

Megaderma spasma: This is a widely distributed species of South Asia and South-east Asia (Csorba et al. 2008), recorded across the Philippines in bamboo thicket, mixed agro-forest, secondary forest, and primary forest habitat, usually found roosting in small groups in caves, tree-hollows, and hollow $\operatorname{logs}$ (Heaney et al. 2010). They are usually the sole occupant of their retreat (Nowak 1994), although they have been observed roosting in caves with other species (Esselstyn et al. 2004). During the present study M. spasma was the most frequently encountered species, confirmed at five of the 17 caves where bats were recorded as being present. The largest group encountered (15 individuals) were the sole occupants of a small undisturbed cave (Cave 13) in a large predominantly disused/overgrown coastal garden in Libertad, and the cave potentially represents a local maternity roosting site for the species. At other caves this species was recorded in lower numbers, but all were in association with other species, including small numbers of E. alecto (Cave 10), C. brachyotis (Cave 9) and Rhinolophus sp. (Caves 5 and 9), and a large maternity roost of $H$. ater (Cave 20). In all cases there was segregation between species, with M. spasma occupying either distinct areas of a cave, or separate caverns. Animals were frequently encountered roosting individually or in small numbers, but huddling together upon disturbance, a behaviour which has been observed elsewhere (Csorba et al. 2008).

\section{CURRENT THREATS}

During the current study, a range of human pressures were either directly observed or identified through discussions with local people which could pose a threat to existing cave bat populations, including harvesting of bats for food, disturbance (through activities including tourism, local cultural use, antisocial behaviour and treasure-hunting) and potential future land-use changes resulting from development.

For the majority of caves visited, the impacts of these pressures currently appear to be limited in extent. There are a number of potential reasons for this; many of the caves are sufficiently remote (Caves 1, 4 and 16), difficult to get into (Caves 6 and 15), difficult to find, even with guides (Caves 15, 20, 21 and other reported caves in Barbaza that couldn't be found), or located in private property (Caves 10-13 and 15). Bat harvesting does appear to pose a more serious threat to the important colony of $R$. amplexicaudatus present at Cave 16 within the Central Panay Mountain Range, given the suggested recent increase in this activity reported by locals. However, the reported cessation of harvesting at Cave 4 in Libertad indicates that locals do understand the consequences of harvesting and are 
taking responsible steps to prevent and reverse historic impacts. Although the harvesting of bat guano has been identified as one of the major threats to cave bats in South-east Asia (Al-Mateen et al. 2011), this activity was not recorded during the current study.

Tourism within Panay is currently limited to Boracay Island, off the north coast of the Northwest Panay Peninsula. Here, the development pressure associated with tourism (land take, increased disturbance) has had negative effects on island's fauna and flora (including bats), and sustainable management of the remaining biodiversity asset is an ongoing challenge (e.g., Luft \& Meier 1999; van der Aa et al. 2006). However, mainland Panay is becoming increasingly more accessible to the foreign traveller; for example, during the current study, a project to completely pave the existing coastal road around the Northwest Panay Peninsula was well underway, and it was evident that the municipality of Libertad has aspirations to develop it's potential as a tourist destination, with an eco-tourist accommodation building project currently in progress. Development could negatively impact on local bat cave populations, both directly (such as at Caves 10 and 12, where the land in which the caves are located was historically allocated for hotel development) and indirectly, through increased tourist visits to wellknown and easily accessible caves (such as at Cave 7). However, if well-planned and undertaken sensitively and with due consideration to bat populations, tourism could help to protect cave bats by providing new and alternative sources of income to local people, as well as supporting organisations currently undertaking research and educational activities on Panay which are beneficial to cave bat conservation.

\section{CONCLUSIONS}

The present study represents the first attempt to record species composition and colony estimates of bats within caves on Panay Island, as well as documenting existing and potential future threats to these populations. Based on the information collected so far, recommended priorities for future work are as follows:

\section{Further baseline studies}

Some of the larger caves in Libertad (Caves 6, 8 and 15), as well as the cave complex in the Central Panay Mountain Range (Cave 16), have only been partially explored, so further visits should be undertaken to enable a comprehensive assessment of the cave structures and the extent to which they are used by bats (including confirmation of all species present). In addition, where larger colonies have either been observed (Cave 6) or are likely to occur (Cave 15), baseline emergence surveys should be undertaken at cave entrances to quantify the numbers of bats present. A more robust and standardised emergence survey method should also be devised for the Cave 16 complex to enable an accurate estimate of this important population.

However, beyond cave-specific recommendations, there is a wider need to assess bat populations within all caves on Panay Island. The first obvious step towards this goal would be to establish a more co-ordinated, comprehensive cave assessment programme for a specific geographic area, such as the entire Northwest Panay Peninsula.

\section{Regular monitoring of key sites}

Ideally, all confirmed bat caves should be monitored on a regular basis, and certainly those caves either confirmed or suspected of supporting breeding colonies (as indicated in Tables 1 and 2). Monitoring should seek to detect any changes in bat populations (through the undertaking of repeatable standard methods employed during baseline studies) and be able to relate any changes observed (whether negative or positive) to identified human pressures. Where resources are limited, priority should be given to monitoring the breeding colonies of $R$. amplexicaudatus at Caves 4, 7 and 16 , as bat harvesting and disturbance from tourism have already been identified as existing pressures which may be impacting on these populations.

\section{Developing a local echolocation call library}

During the present study a limited amount of opportunistic echolocation call data was collected as a tool to aid with species identification. Whilst this data did provide some additional information (particularly regarding horseshoe bats), the recording of echolocation calls is currently of limited use as a surveying technique due to the lack of reference call libraries with which collected data can be compared (Sedlock 2001). There is therefore an urgent need 
to begin compiling a local reference call library for Panay, using calls recorded under more standardised conditions.

\section{Protection of key sites and managing threats and pressures}

Cave 16 within the Central Panay Mountain Range supports a significantly large fruit bat colony which is currently under threat from increased bat harvesting. This cave therefore appears to be of sufficient importance to warrant inclusion within a protected area, and the information collected so far should therefore be fed into current work being undertaken by the Haribon Foundation to expand the existing boundaries of the Central Panay Mountain Range protected area. However, as has already been highlighted, on its own the protected areas system currently receives insufficient funding to ensure that effective conservation measures are undertaken. In addition there is therefore a need to educate and work with local barangays to ideally stop, or at least reduce the level of bat harvesting at the cave. There is also some potential for establishing the cave as a more extreme tourist attraction, offering a combination of rainforest hiking, river rafting, wildlife watching, and a unique cultural experience - if this was implemented sensitively, it could help with the cave's protection by providing an alternative economic benefit to the local barangays (through employment of guides, provision of accommodation etc).

More widely there is a need to raise awareness about the conservation of bats and the importance of local cave systems for their survival with local communities and governments, and to provide advice on sustainable cave management. For example, discussing the need to regulate visits to Cave 7 in Libertad with the municipality environment officer, and exploring opportunities for positive, long-term stewardship of Caves $10-13$ and 15 with the private landowner. Organisations such as PSDCF are well placed to facilitate these actions on the ground, and bat research and education activities could be built into a regular programme of work involving both local groups and international volunteers. However, such activities should not be undertaken in isolation, but rather they should be implemented in a co-ordinated approach with other organisations, such as Bat Conservation International (BCI) and the Southeast
Asian Bat Conservation and Research Unit, who have shared aspirations for bat conservation and are already developing and implementing complimentary work programmes. BCI has initiated a specific work programme focused on supporting efforts to conserve cave-bats of the Philippines, and there are potential opportunities for the sharing of information, experiences and expertise, such as through the Philippine Caves and Bats website $<$ https: $/ /$ phcavebats. crowdmap.com>.

\section{REFERENCES}

Al-Mateen, X., A. Alias, N. Furey, N.R. Ingle, K. Phelps, J.L. Sedlock \& D. Waldien (2011). Participants Weigh In on the Status of Cave Bats in South-east Asia. Report to the $2^{\text {nd }}$ International Southeast Asian Bat Conference $<\mathrm{http}$ :// www.seabcru.org/index.php/cave-bats/72-conferenceparticipants-weigh-in-on-the-status-of-cave-bats-insoutheast-asia>

Bonaccorso, F.J. (1998). Bats of Papua New Guinea. Conservation International, Washington D.C., 489pp.

Campbell, P., C.J. Schneider, A.M. Adnan, A. Zubaid \& T.H. Kunz (2004). Phylogeny and phylogeography of Old World fruit bats in the Cynopterus brachyotis complex. Molecular Phylogenetics and Evolution 33: 764-781.

Churchill, S.K. (2008). Australian Bats (2 ${ }^{\text {nd }}$ Edition). Allen and Unwin, Sydney, 255pp.

Csorba, G., S. Bumrungsri, C. Francis, P. Bates, M. Gumal, T. Kingston, S. Molur \& C. Srinivasulu (2008). Hipposideros ater. Megaderma spasma, Rousettus amplexicaudatus. In: IUCN 2011. IUCN Red List of Threatened Species. Version 2011.1. <www.iucnredlist. org $>$. Downloaded on 01 October 2011.

Curio, E., A. Hamann \& L.L. Lastimoza (1996). The appearance and status of the Wrinkled Hornbill (Aceros waldeni) on Panay. Oriental Bird Club Bulletin 23: 18-20.

DENR-PAWB (2009). Cave Classification Handbook. Department of Environment and Natural ResourcesProtected Areas and Wildlife Bureau, Quezon City, Philippines, 62pp.

Dumont, E.R. (2003). Bats and fruit: an ecomorphological approach, pp. 398-429. In: Kunz, T.H. \& M. Brock Fenton (eds.). Bat Ecology. The University of Chicago Press, Chicago and London, $x i x+779 p p$.

Esselstyn, J.A., P. Widmann \& L.R. Heaney (2004). The mammals of Palawan Island, Philippines. Proceedings of the Biological Society of Washington 117: 271-302.

Esselstyn, J.A. (2007). A new species of Stripe-faced Fruit Bat (Chiroptera: Pteropodidae: Styloctenium) from the Philippines. Journal of Mammalogy 88: 951-958.

Galang, R. \& D.A. Madulid (2006). A second new species of Rafflesia (Rafflesiaceae) from Panay Island, Philippines. 
Folia Malaysiana 7(1): 1-8.

Gaulke, M. \& E. Curio (2001). A new monitor lizard from Panay Island, Philippines (Reptilia, Sauria, Varanidae). Spixiana 24: 275-286.

Heaney, L.R. (1993). Biodiversity patterns and the conservation of mammals in the Philippines. Asia Life Sciences 2: 261274.

Heaney, L.R., D.S. Balete, M.L. Dolar, A.C. Alcala, A.T.L. Dans, P.C. Gonzales, N.R. Ingle, M.V. Lepiten, W.L.R. Oliver, P.S. Ong, E.A. Rickart, B.R. Jr Tabaranza \& R.C.B. Utzurrum (1998). A synopsis of the mammalian fauna of the Philippine Islands. Fieldiana: Zoology 88: $1-66$.

Heaney, L.R. \& J.C. Jr. Regalado (1998). Vanishing Treasures of the Philippine Rain Forest. The Field Museum, Chicago, 88pp.

Heaney, L.R., E.K. Walker, B.R. Jr Tabaranza \& N.R. Ingle (2000). Mammalian diversity in the Philippines: an assessment of the adequacy of current data. Sylvatrop, The Technical Journal of the Philippine Ecosystems and Natural Resources 10(1): 6-27.

Heaney, L.R., M.L. Dolar, D.S. Balete, J.A. Esselstyn, E.A. Rickart \& J.L. Sedlock (2010). Synopsis of Philippine Mammals $<$ http://archive.fieldmuseum.org/philippine mammals $>$. The Field Museum of Natural History in cooperation with the Philippine Department of Environment and Natural Resources - Protected Areas and Wildlife Bureau.

Heideman, P.D. \& R.C.B. Utzurrum (2003). Seasonality and synchrony of reproduction in three species of nectarivorous Philippines bats. BioMed Central Ecology 3: 11.

Hutson, A.M., S.P. Mickleburgh \& P.A. Racey (compilers) (2001). Microchiropteran Bats: Global Status, Survey and Conservation Action Plan. International Union for Conservation of Nature and Natural Resources, Chiroptera Specialist Group (IUCN/SSC). Gland, Switzerland, 259pp.

Ingle, N.R. \& L.R. Heaney (1992). A key to the bats of the Philippine Islands. Fieldiana: Zoology 69: 1-44.

Klop, E., E. Curio \& Y. de Soye (1998). A new population of bleeding-heart pigeon (Gallicolumba sp.) and its conservation relevance on Panay, Philippines. Journal of Ornithology 139: 76-77.

Luft, S., \& G. Meier (1999). Give Nature a Chance - Tourism on Boracay. Journal on Environment, Energy and Minerals 2: 28-32.

Locke, R. (2006). A treasure trove of fruit bats. Bats 24(4): $1-7$.

Mendoza, M.M. \& N.A.D. Mallari (1997). Philippine Red Data Book. Wildlife Conservation Society of the Philippines, Bookmark Inc., Philippines, 262pp.

Mickleburgh, S.P., A.M. Hutson \& P.A. Racey (compilers) (1992). Old World Fruit Bats. An Action Plan for their
Conservation. International Union for Conservation of Nature and Natural Resources, Chiroptera Specialist Group (IUCN/SSC). Gland, Switzerland, 252pp.

Mickleburgh, S.P., A.M. Hutson \& P.A. Racey (2002). A review of the global conservation status of bats. Oryx 36(1): $18-34$.

O'Malley, R., R.A. King, C.S. Turner, S. Tyler, M. Cummings \& P. Raines (2006). The diversity and distribution of the bat fauna (Mammalia, Chiroptera) of Danjugan Island Cauayan, Negros Occidental, Philippines. Biodiversity and Conservation 15: 43-56.

Oliver, W.L.R. \& L.R. Heaney (1996). Biodiversity and conservation in the Philippines. International Zoo News 43: 329-337.

Nowak, R.M. (1994). Walker's Bats of the World. The Johns Hopkins University Press, Baltimore and London, 288pp.

Payne, J., C.M. Francis \& K. Phillipps (2005). A Field Guide to the Mammals of Borneo (fourth reprint). The Sabah Society, Kota Kinabalu, 332pp.

Pedregosa, M.dG. (2005). Panay Island: the dwindling forest and its threatened wildlife, an ethnobiological survey. Unpublished report to the North of England Zoological Society, Fauna \& Flora International, \& the Philippines Biodiversity Conservation Programme, 54pp.

Reiter, J. \& E. Curio (2001). Home range, roost switching, and foraging area in a Philippine fruit bat (Ptenochirus jagori). Ectotropica 7: 109-113.

Reiter, J., E. Curio, B. Tacud, H. Urbina, \& F. Geronimo (2006). Tracking bat-dispersed seeds using fluorescent pigment. Biotropica 38(1): 64-68.

Sedlock, J.L. (2001). Inventory of insectivorous bats of Mount Makiling, Philippines using echolocation call signatures and a new trap tunnel. Acta Chiropterologica 3(2): 163-178.

Subade, R. \& E. Jugado (2010). Economic valuation of conserving endangered species and their habitats in the North Western Panay Peninsula, Central Philippines. Economy and Environment Program for Southeast Asia, Singapore, 40pp.

Tan, K.H., A. Zubaid \& T.H. Kunz (1997). Tent construction and social organization in Cynopterus brachyotis (Müller) (Chiroptera: Pteropodidae) in Peninsular Malaysia. Journal of Natural History 31: 1605-1621.

Turner, A., E. Sanderson, M. Sweet \& P. Raines (2006). The biodiversity of the lower-montane forest habitats of the North Negros Forest Reserve, Negros Occidental, Philippines. Coral Cay Conservation, London, 58pp.

van der Aa, P.J.H., R.P. Lorica \& J. Komdeur (2006). The hormonal and behavioral response to the presence and activities of humans in three co-roosting flying fox species (Acerodon jubatus, Pteropus vampyrus and $P$. hypomelanus) in Boracay and Mambukal in the Philippines. Acta Zoologica Sinica 52: 827-837. 

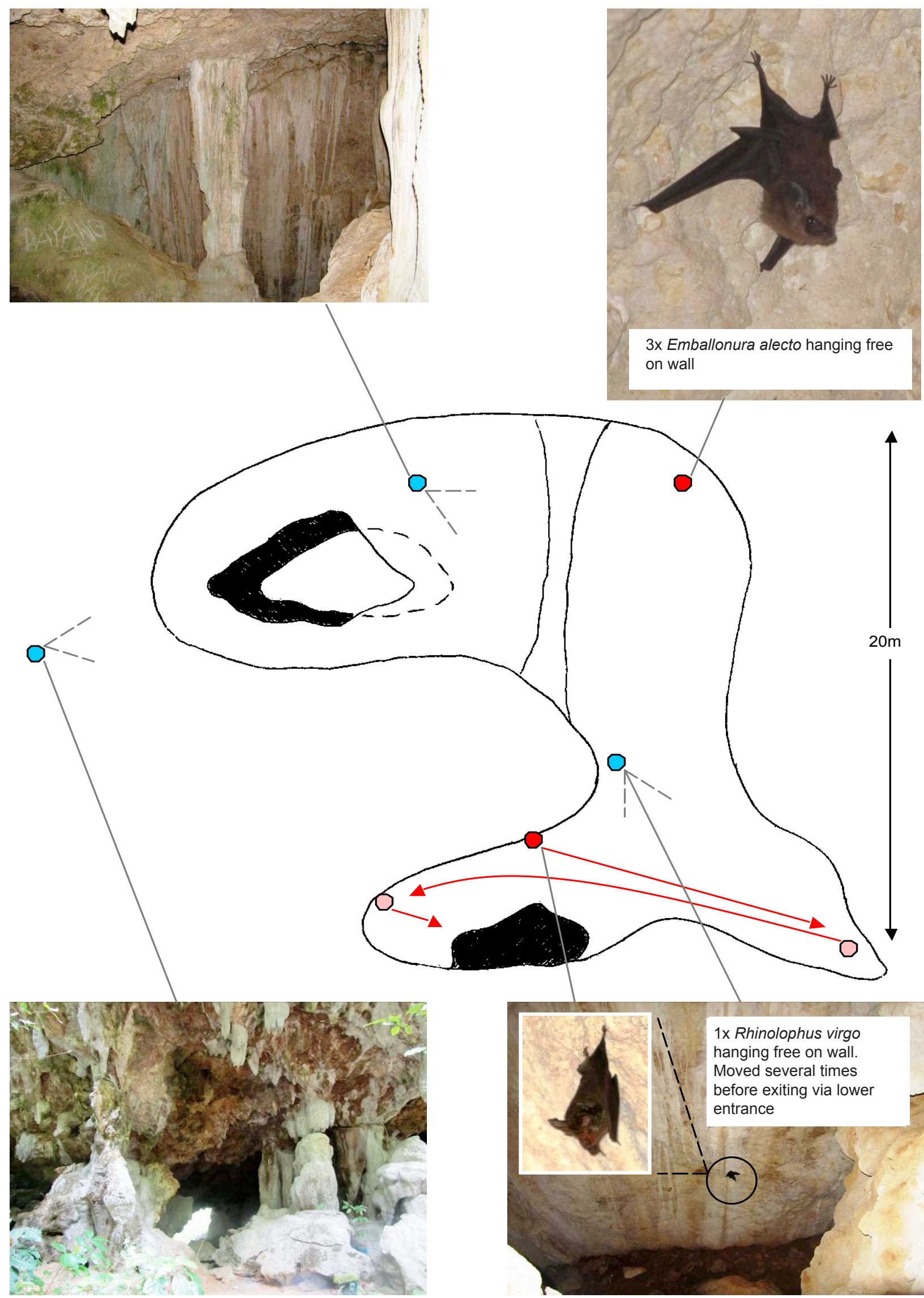

Appendix 1. Illustration of Cave 1, and images of the upper entrance, portions of the cave interior, and of bats in the cave. 


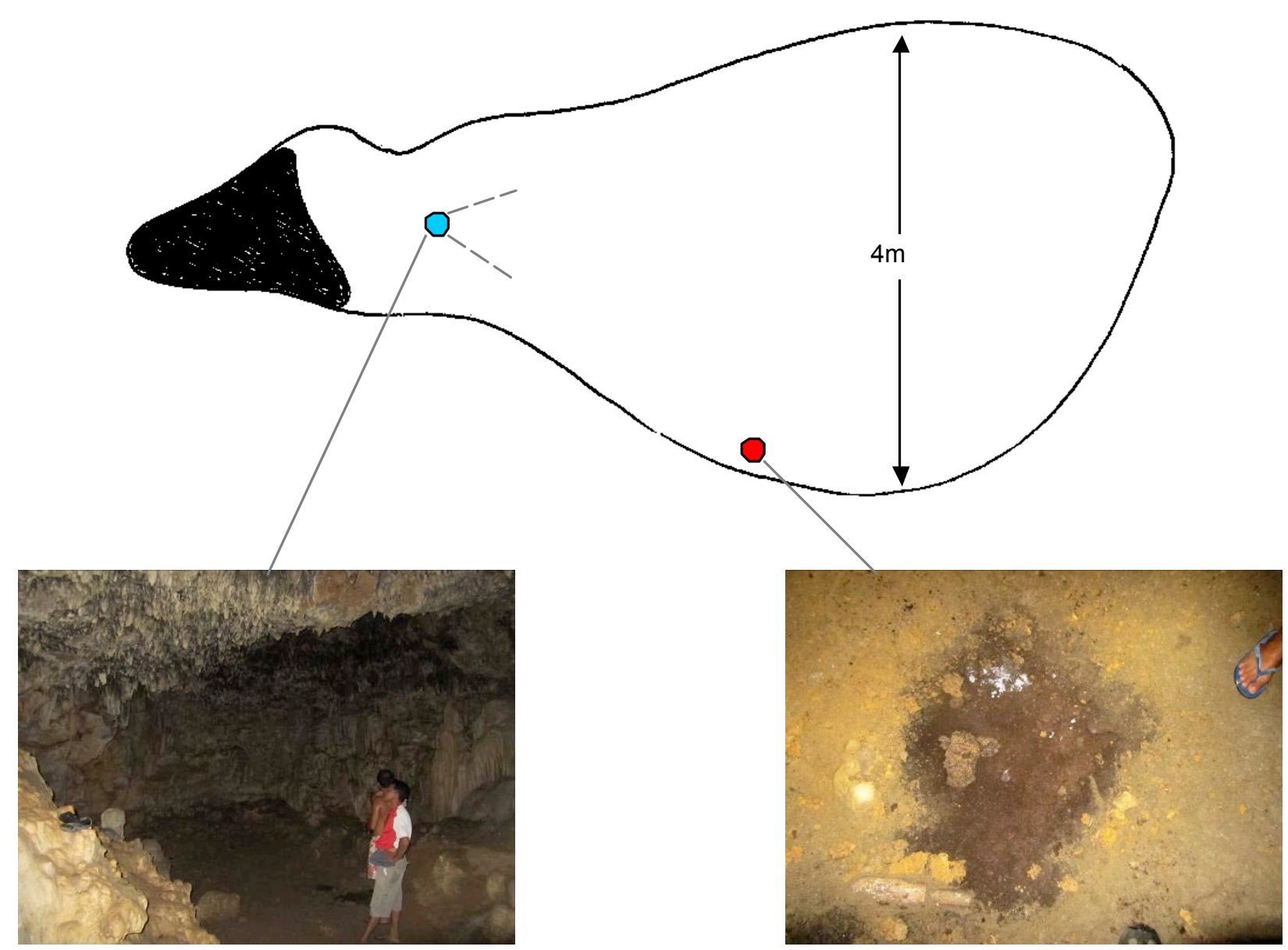

Appendix 2. Illustration of Cave 2, images of a portion of the cave interior and of mircobat droppings on the cave floor. 


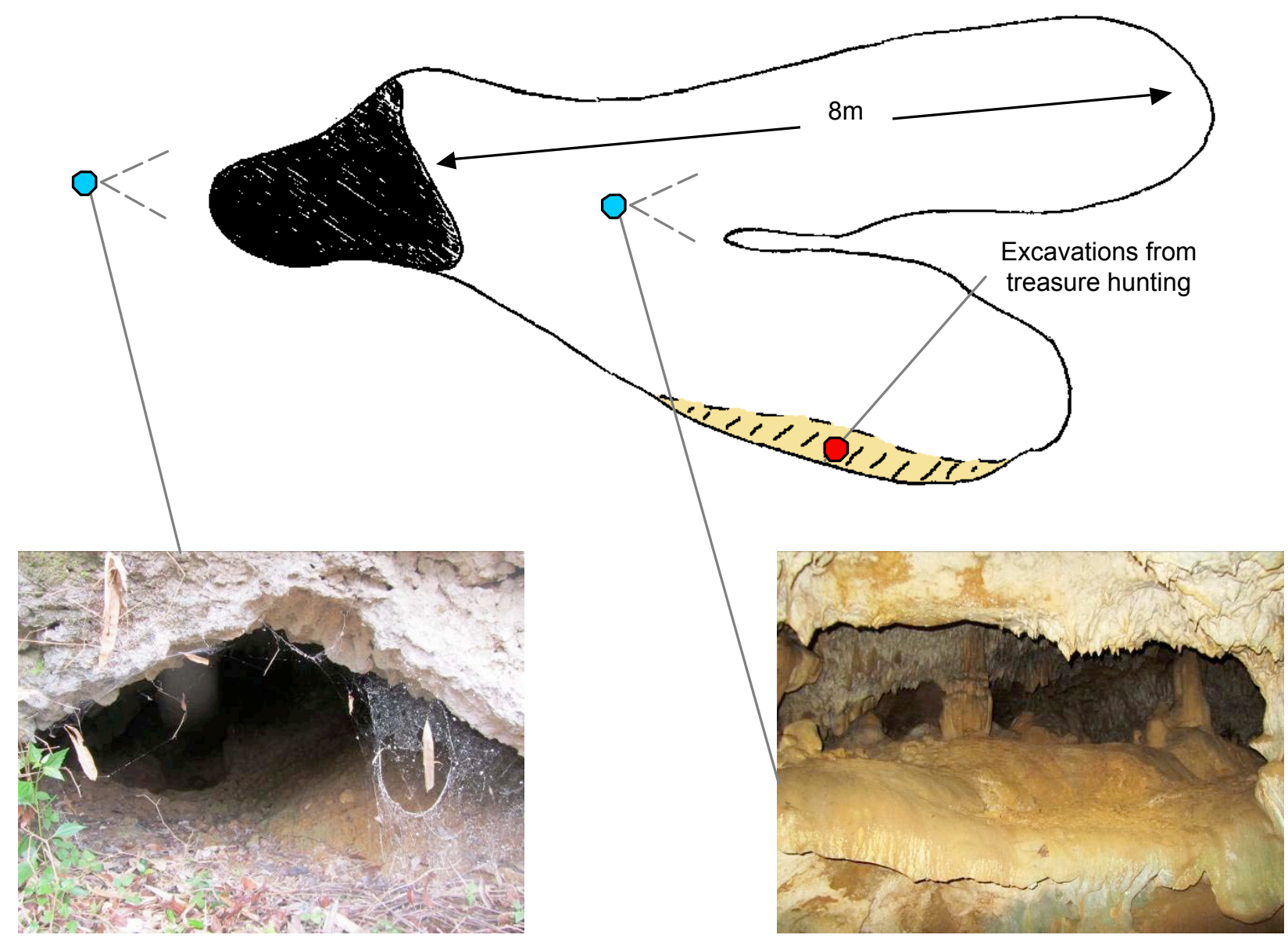

Appendix 3. Illustration of Cave 3, and images of the entrance and an inside portion of the cave. 


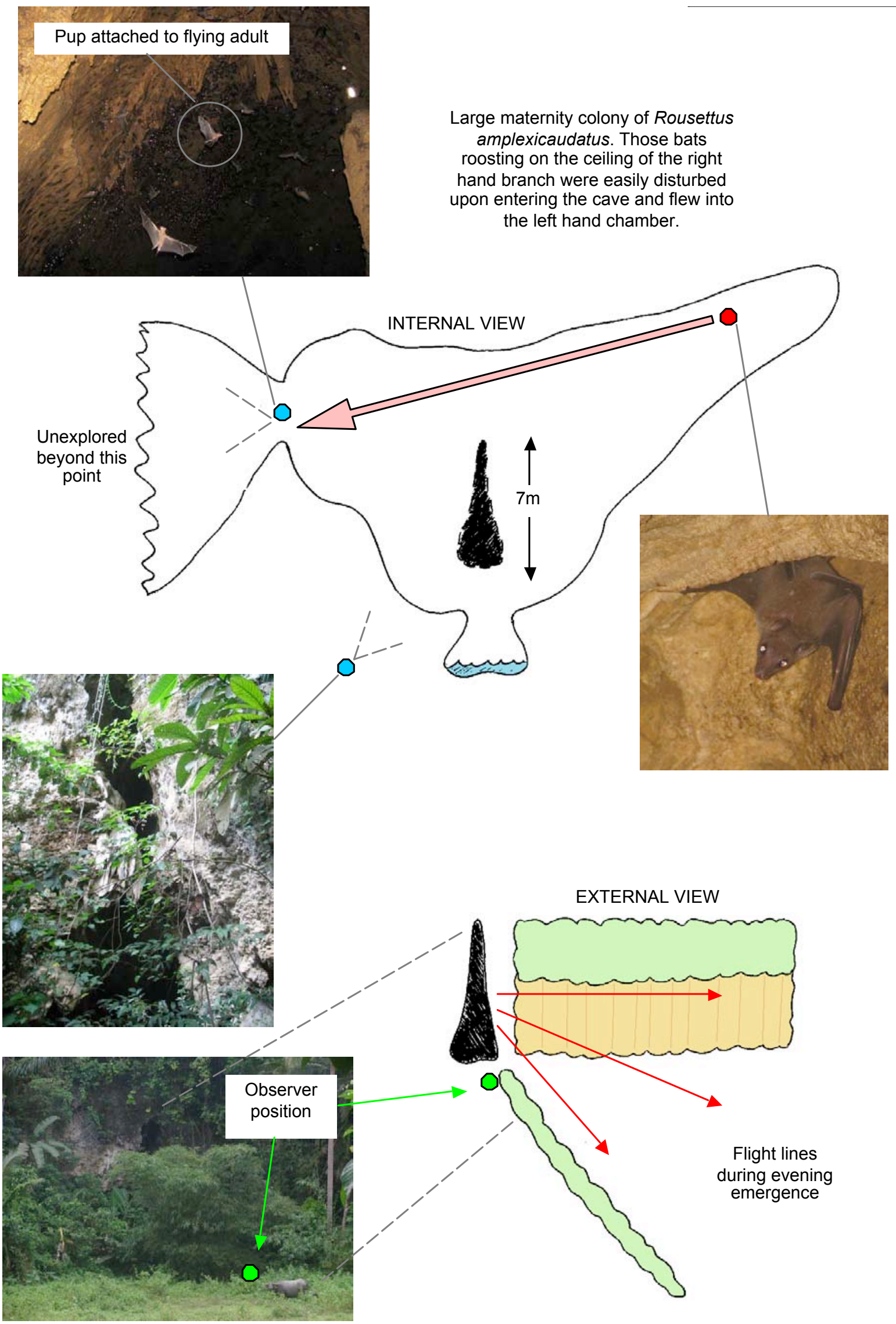

Appendix 4. Illustration of Cave 4, images of portions of the cave interior, of bats in the cave, and cave entrance. 


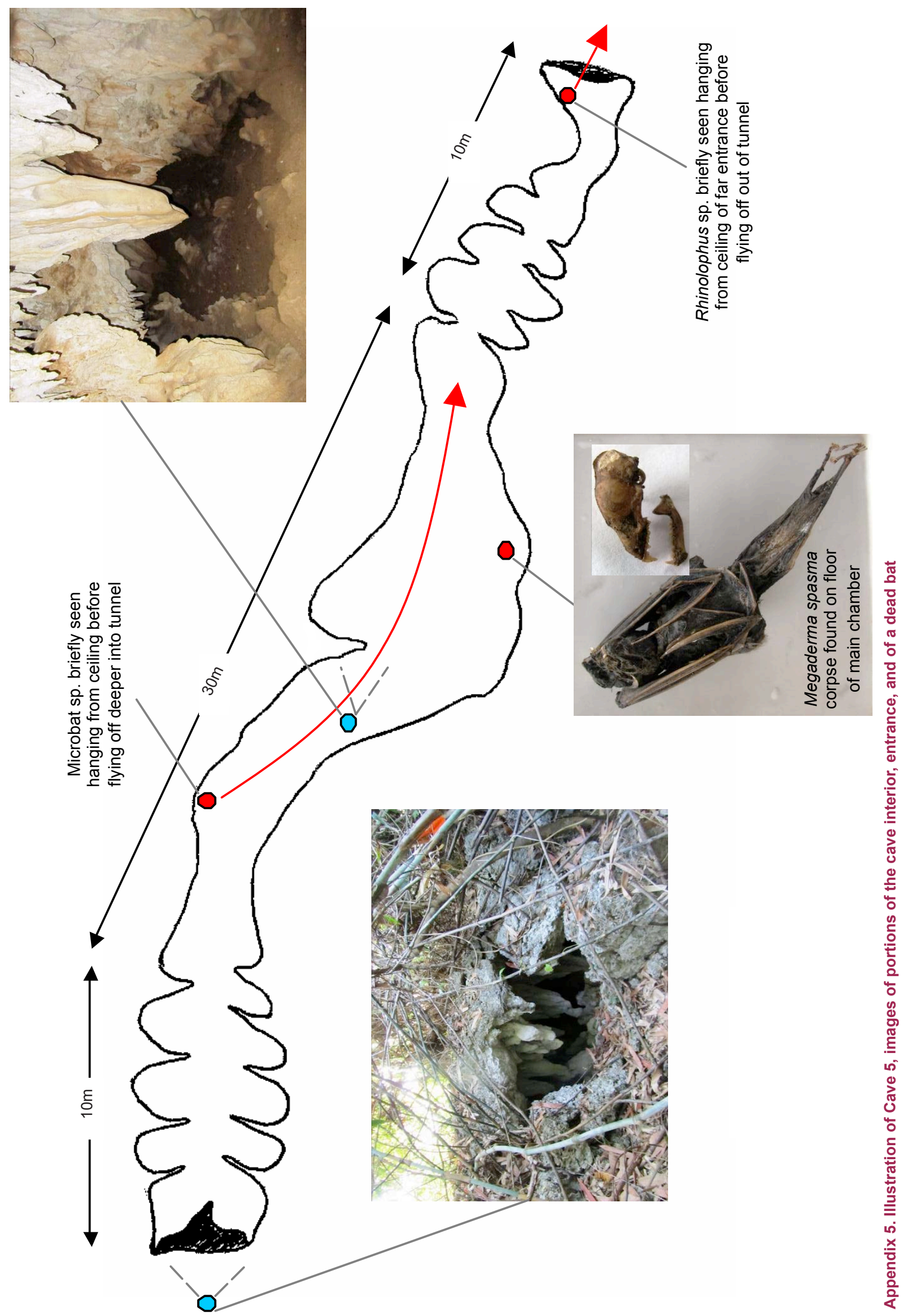




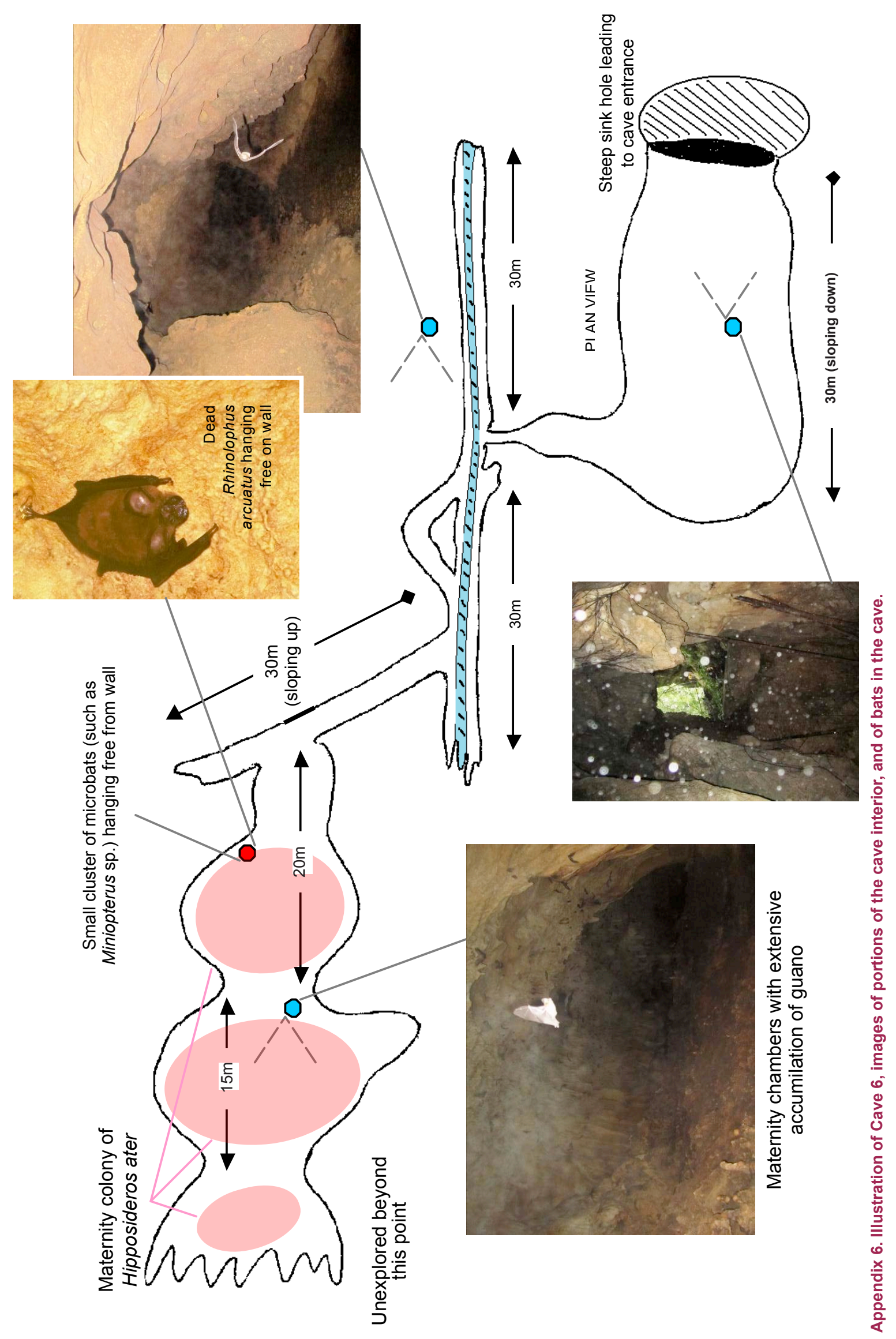




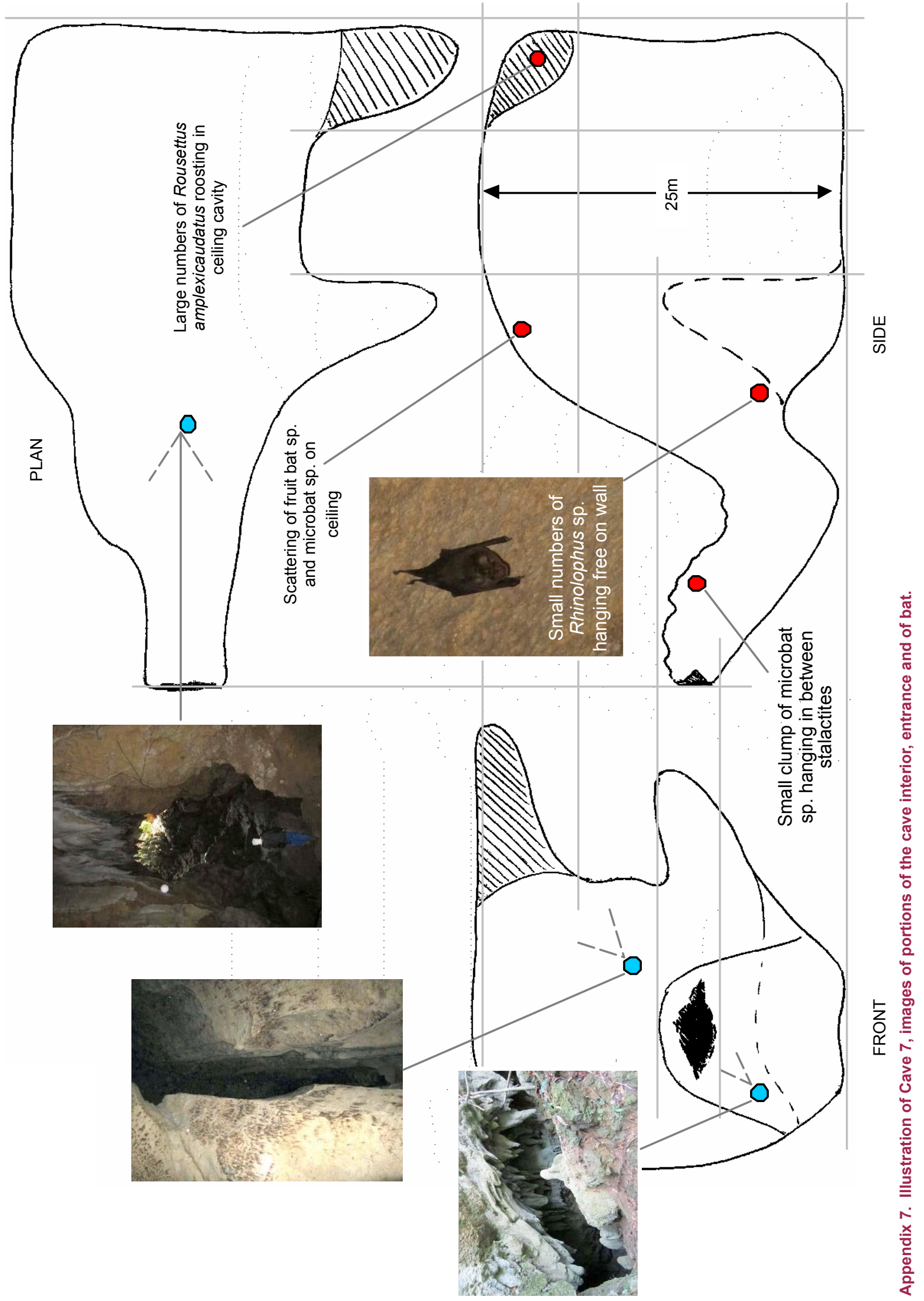




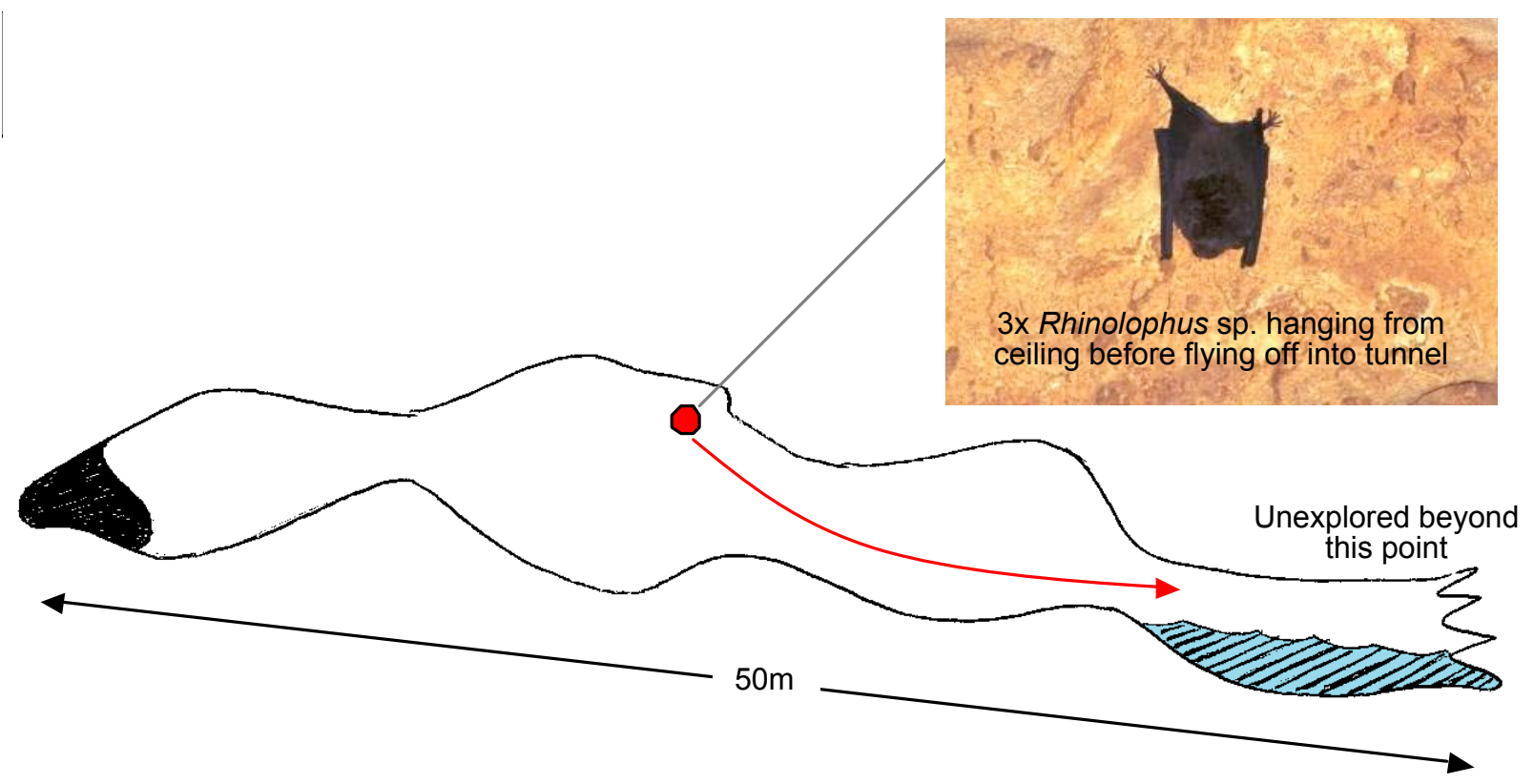

Appendix 8. Illustration of Cave 8, and image of a bats in the cave.

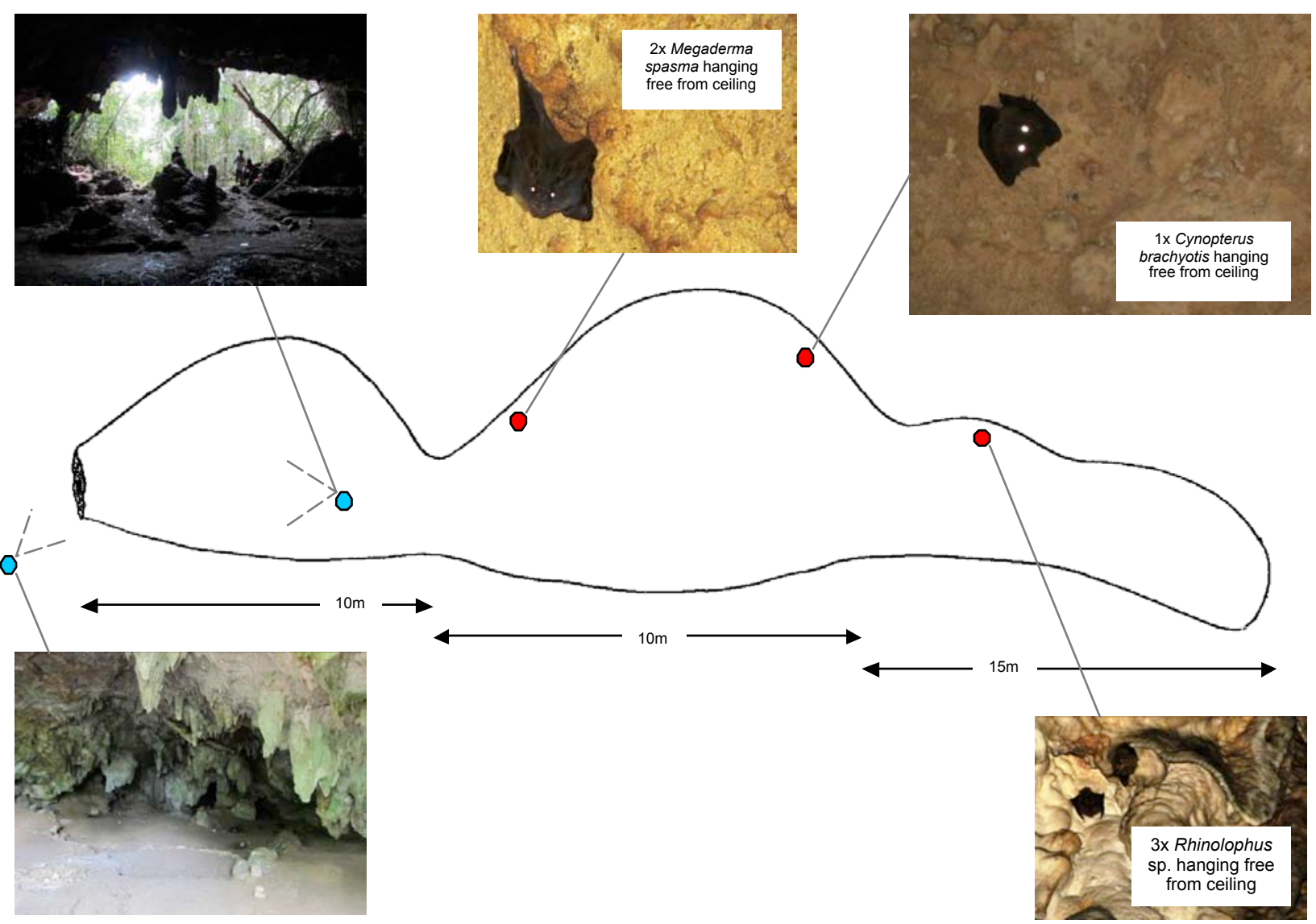

Appendix 9. Illustration of Cave 9, images of portions of the cave interior, the entrance, and of bats in the cave. 

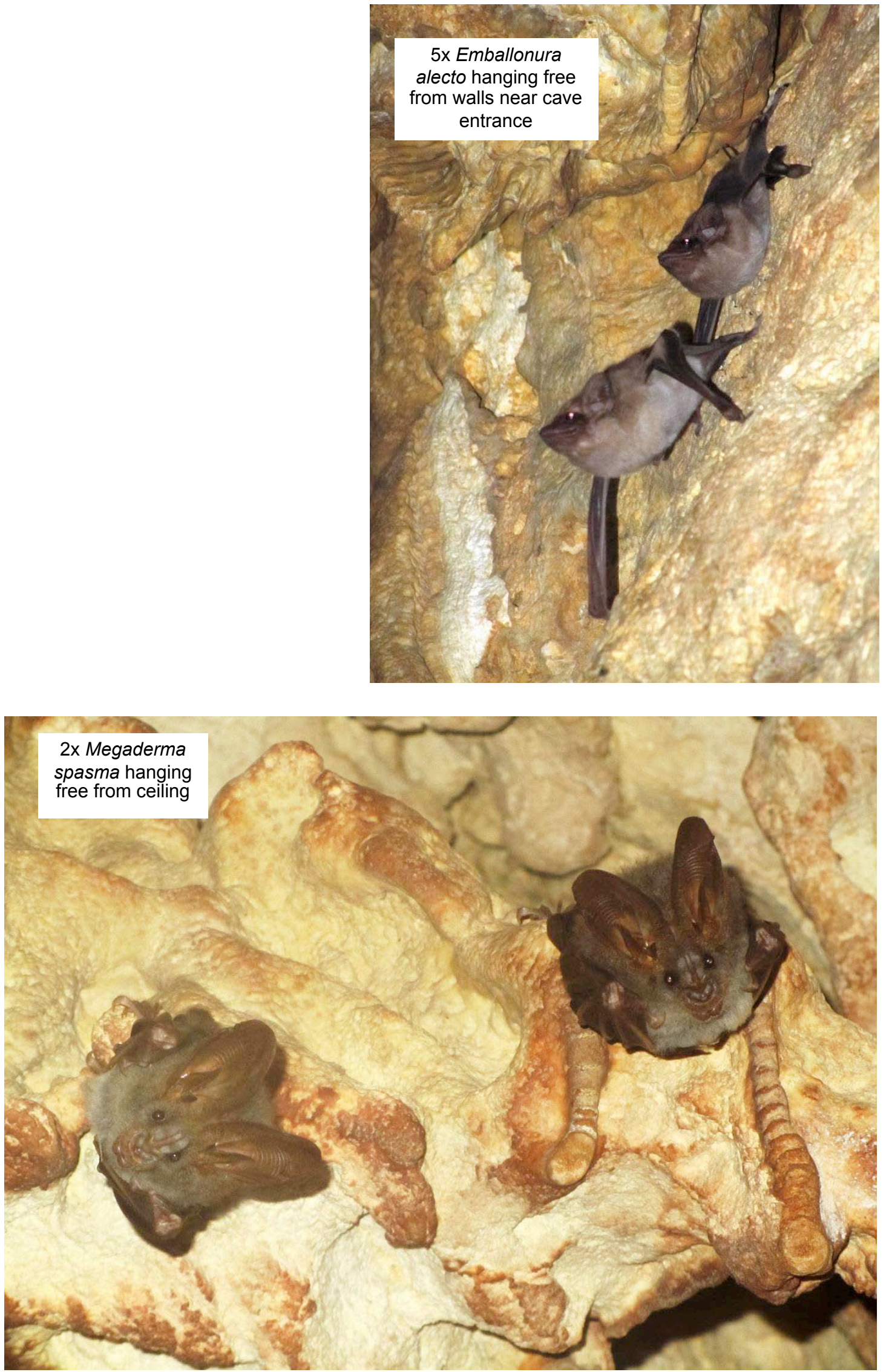

Appendix 10. Images of bats in Cave 10. 


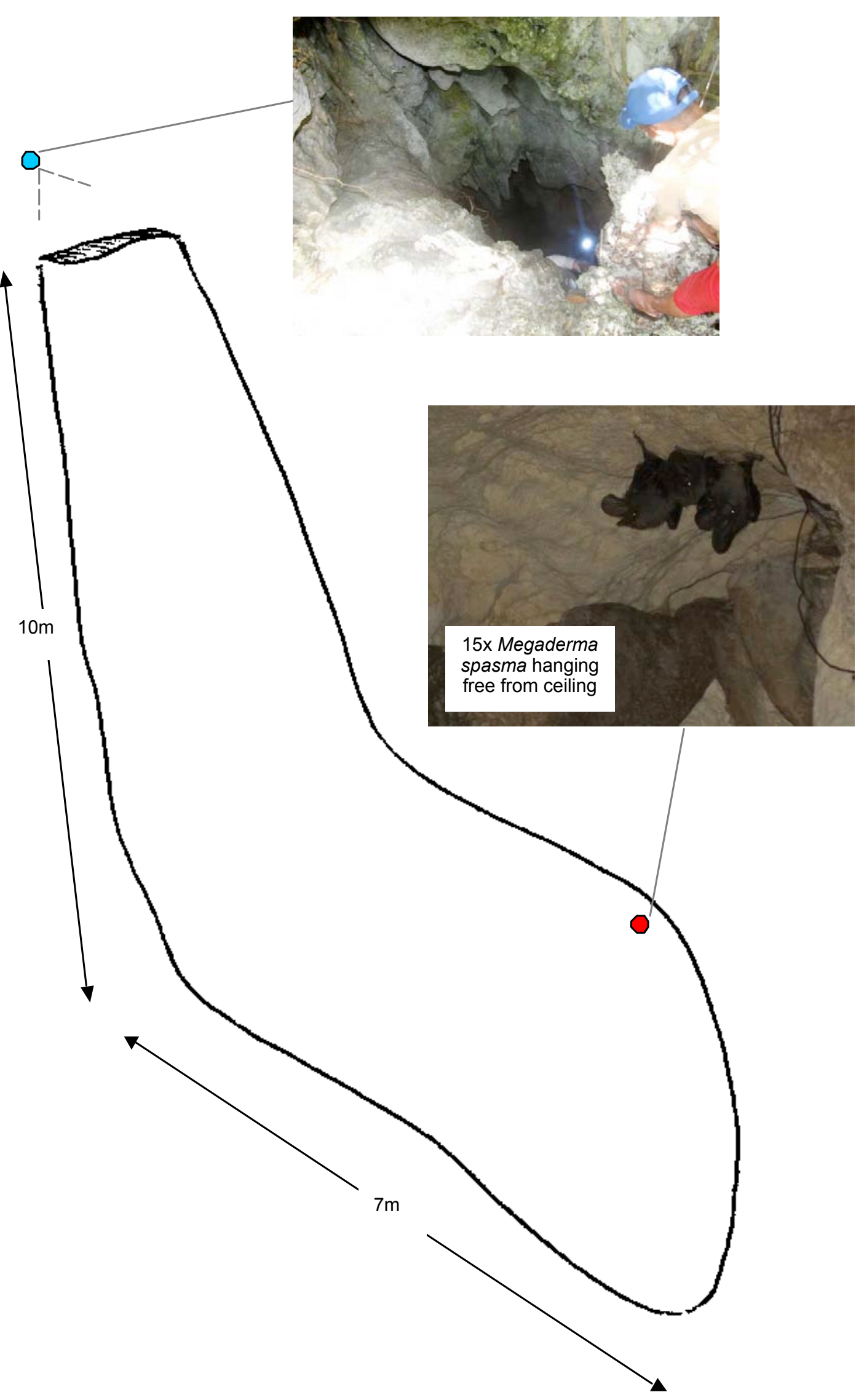

Appendix 11. Illustration of Cave 12, images of the entrance to the cave, and of bats in the cave. 


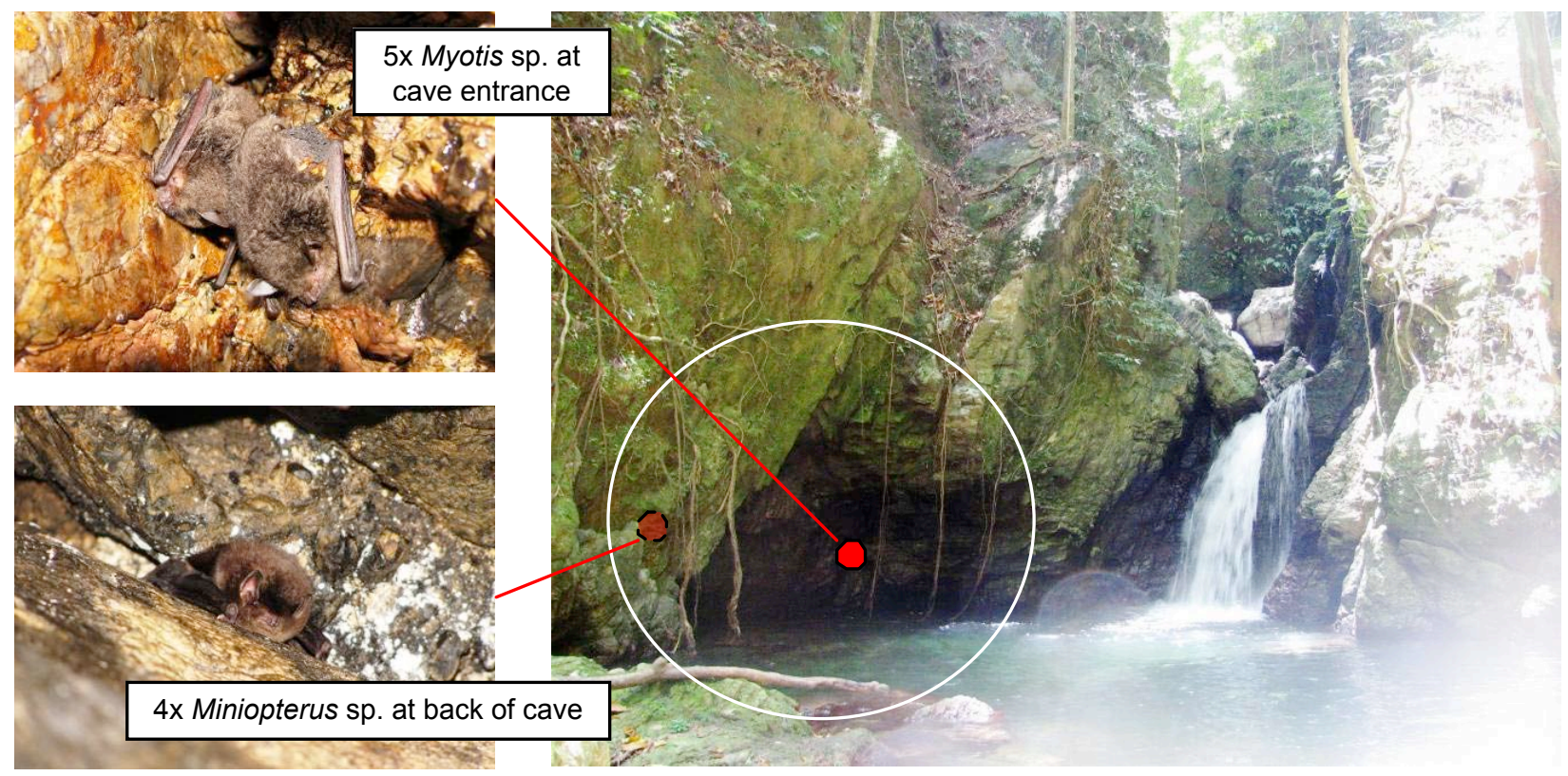

Appendix 12. Illustration of Cave 14, images of entrance to the cave, and of bats in the cave. 


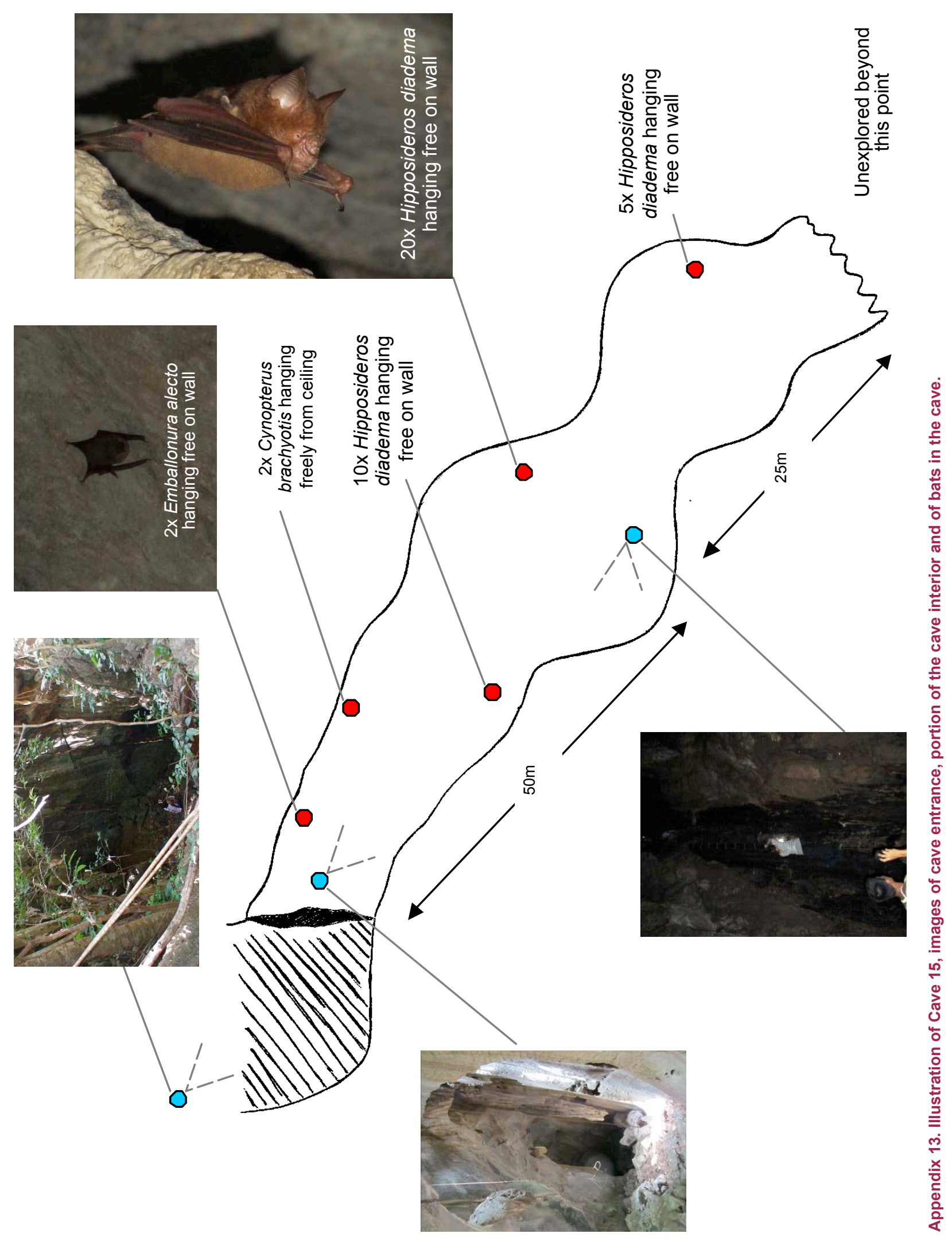



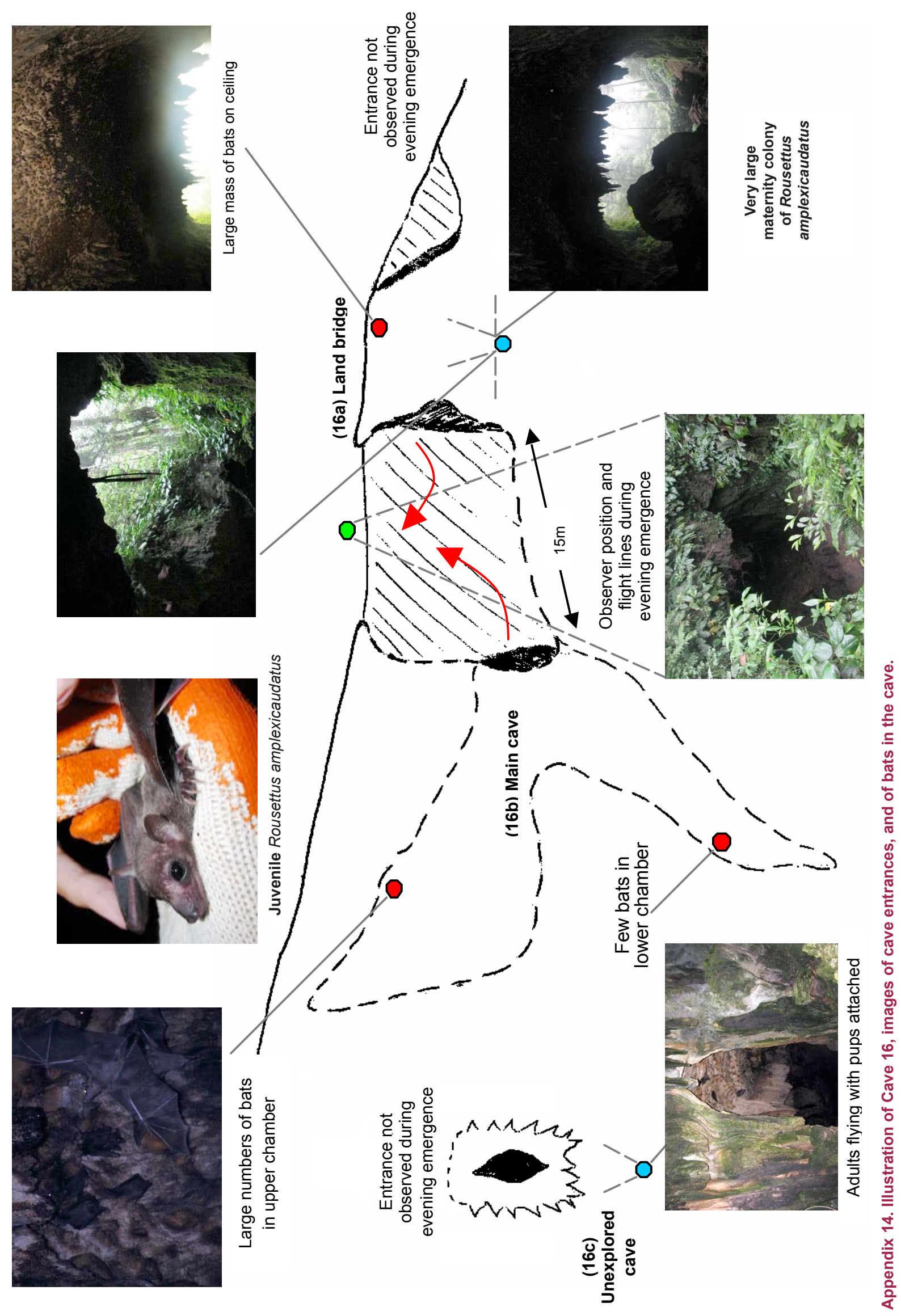


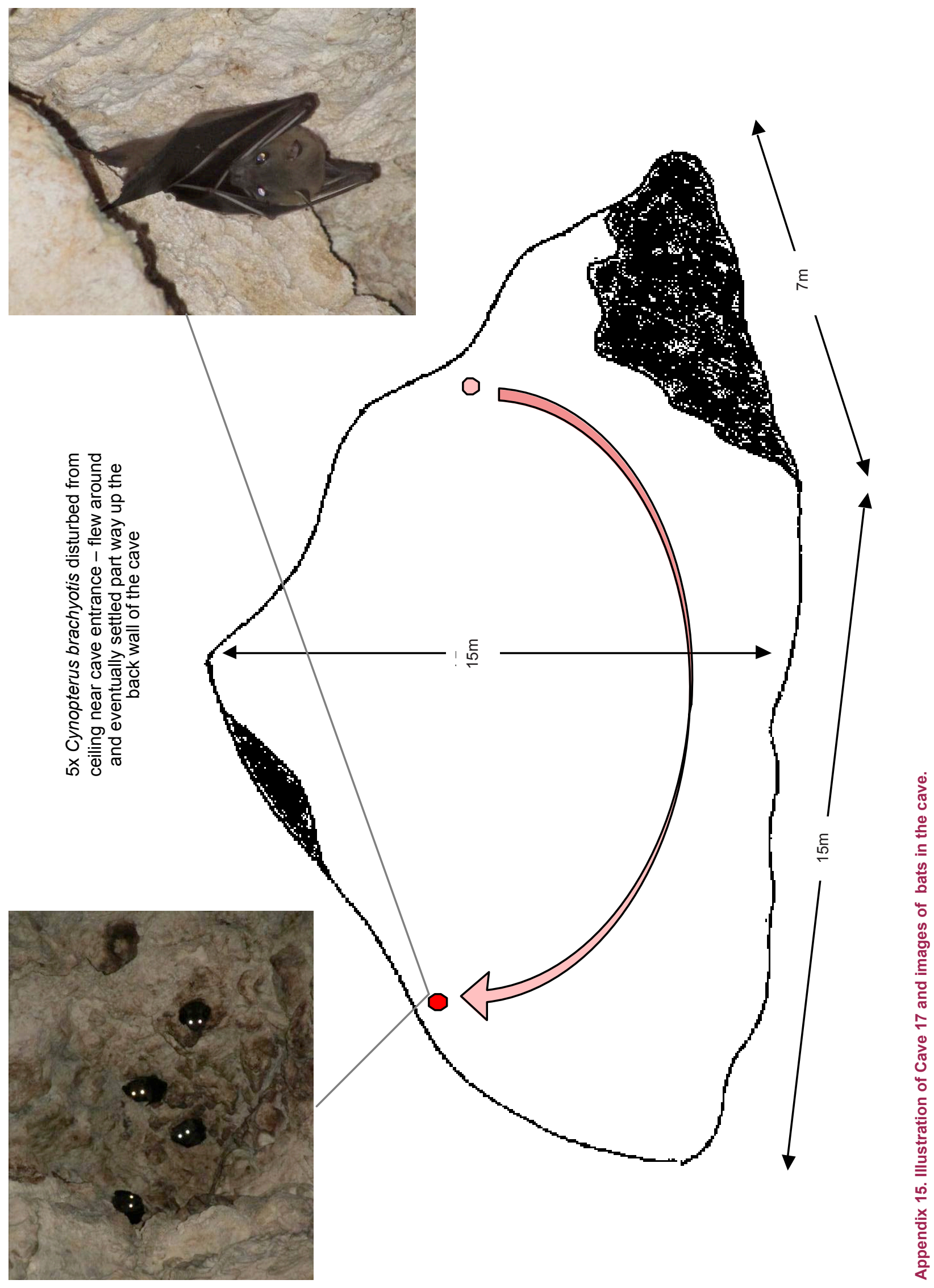

Journal of Threatened Taxa | www.threatenedtaxa.org | September 2012 | 4(11): 2993-3028 


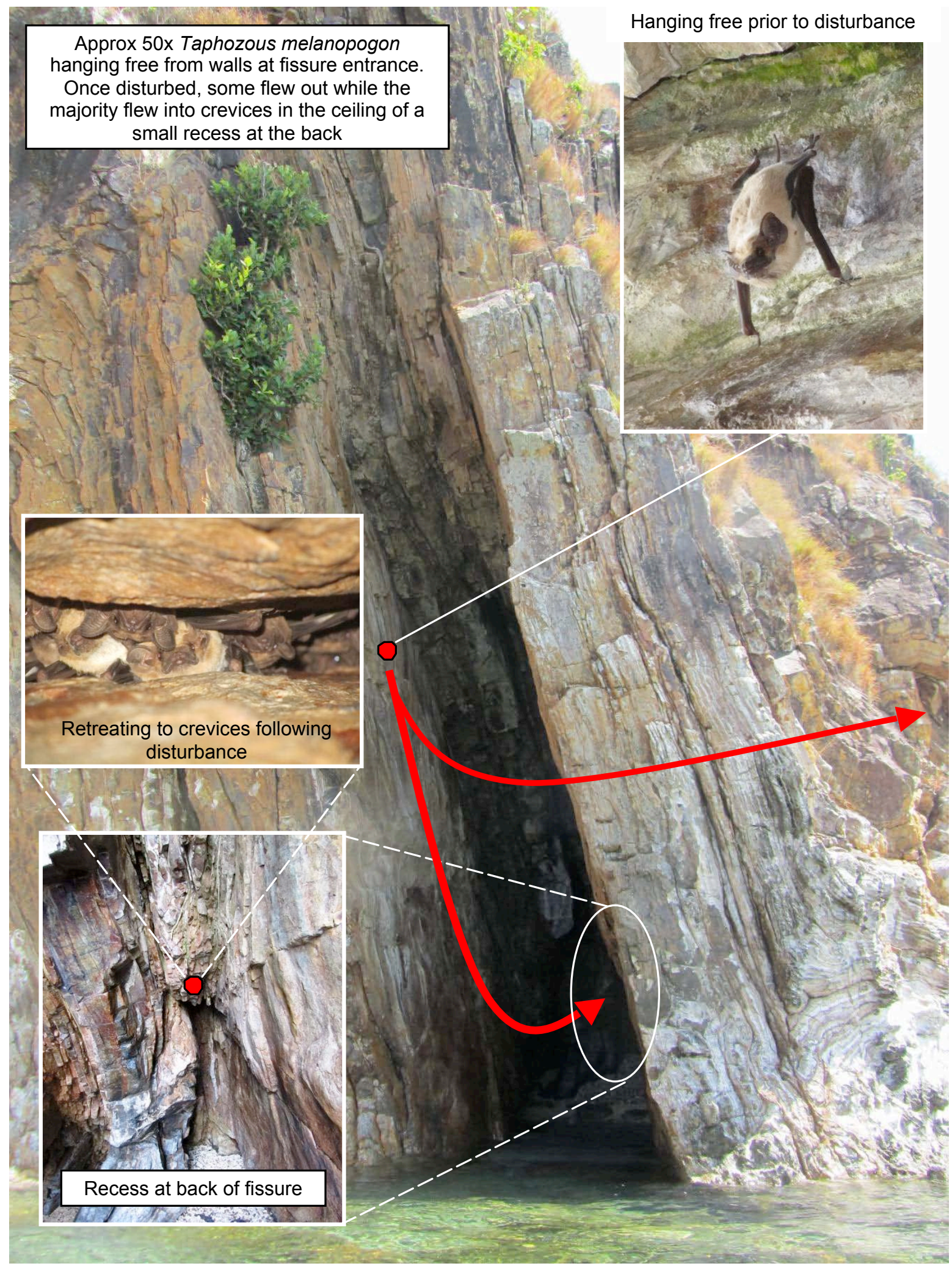

Appendix 16. Images of entrance and interiors of Cave 18, and of bats in the cave. 


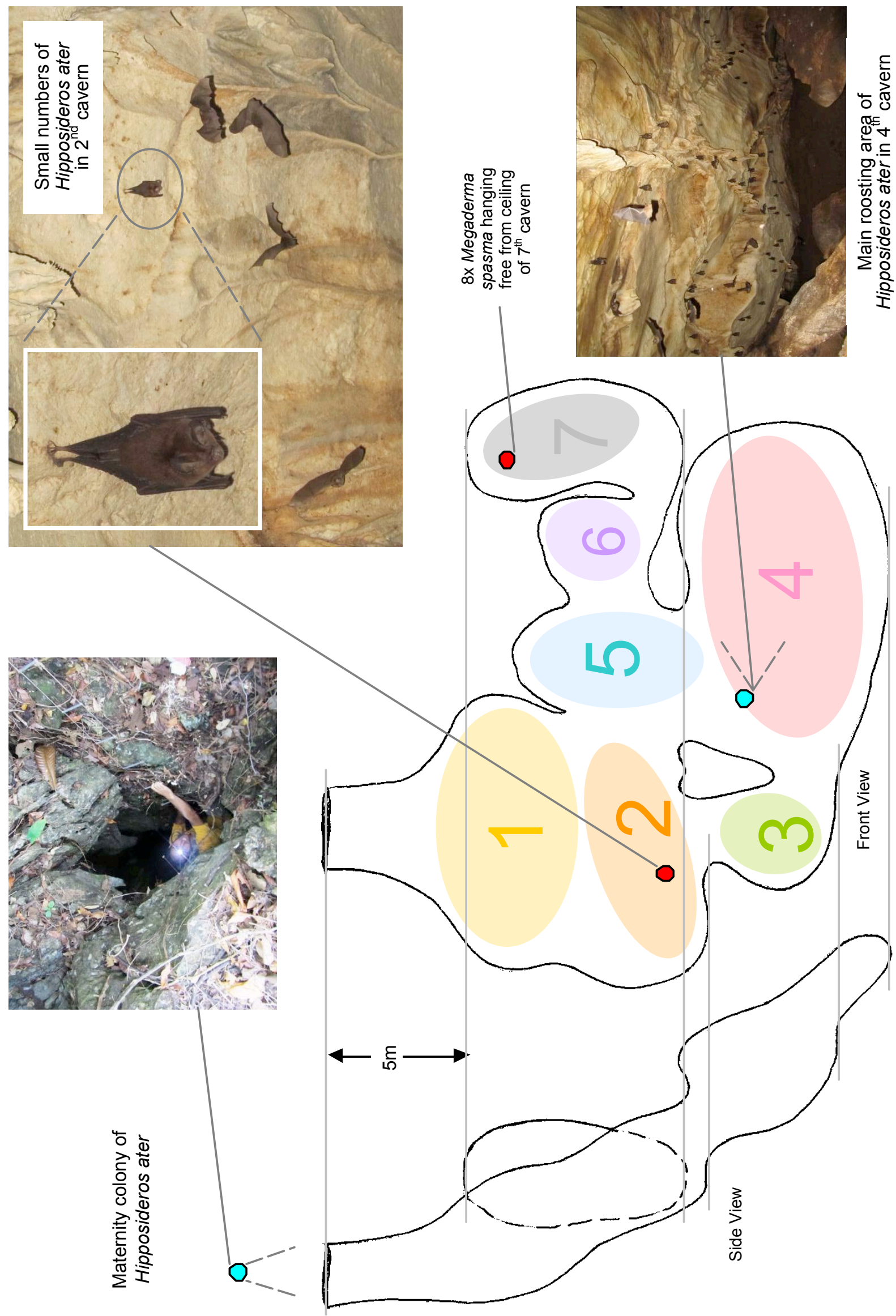

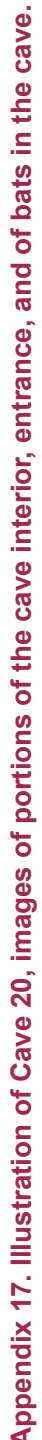




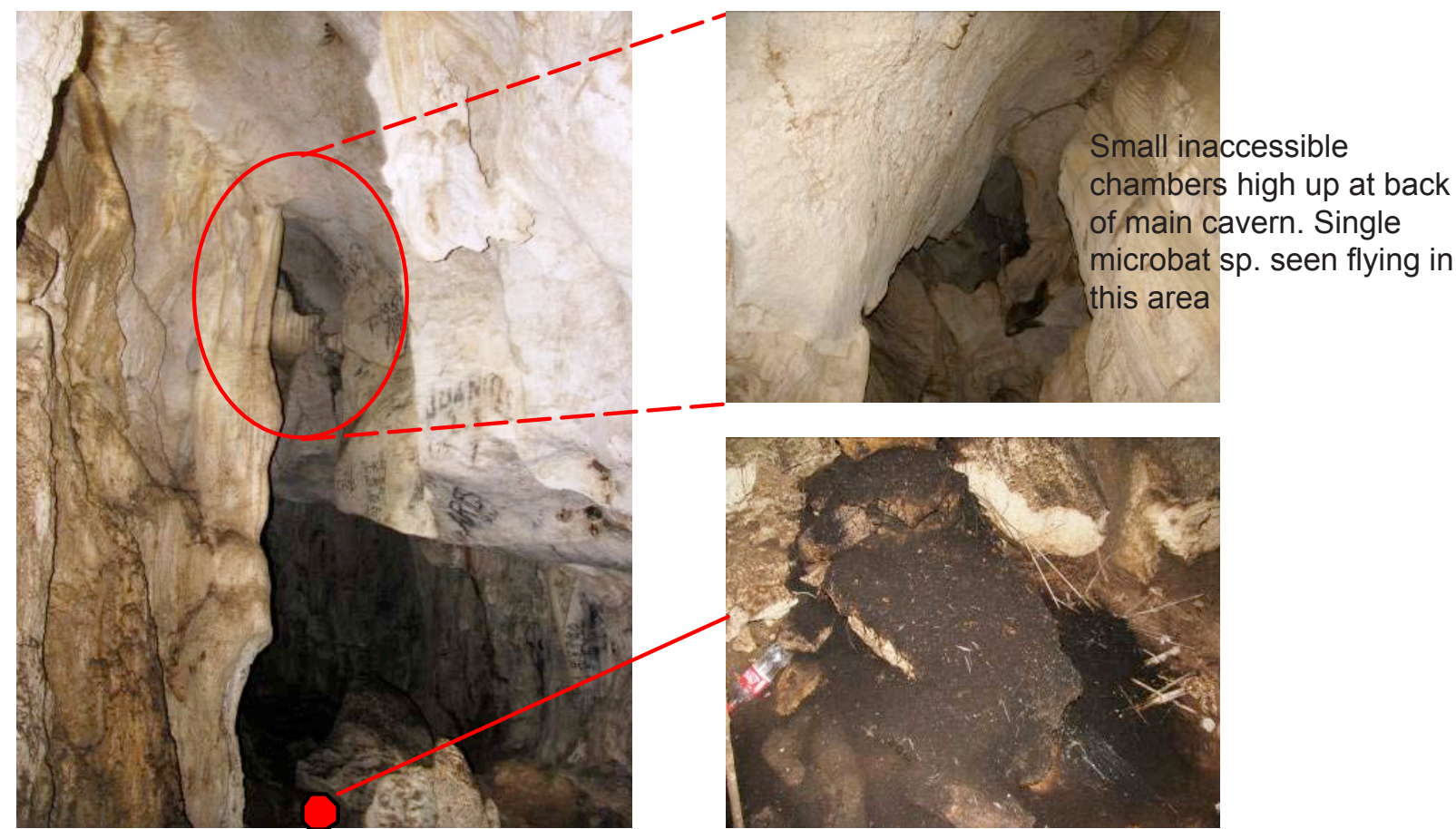

Appendix 18. Images of interiors of Cave 21 and of microbat droppings on floor near cave entrance.

Author Details: ANTONY Mould works within the environmental sector in England, and is actively involved in promoting bat conservation as a member of the Cambridgeshire Bat Group. He has participated in overseas research projects on seabirds in Alaska, and bats in Tasmania, and he undertook the present research whilst volunteering for the Philippine Spotted Deer Conservation Foundation.

Acknowledgements: I would like to thank the following people for their help and assistance during the fieldwork undertaken as part of this project: Raphael Mateo, Reggie Mateo, Claire Celestino, Herbert Magluyan, Raymond Magluyan, Nilo, Bo Bong, Woody Montana, Lindsay, Donna Rana (DENR), Aida Laggie, Norberto P. Raymundo Jr. (Mayor of Libertad), Faith Francisco (Mayor of Barbaza), Christian and Remy, and Julie Danby. Specia thanks to Renee Galang (under whose Gratuitous Permit the current study has been undertaken) for allowing me to participate on the PSDCF project and encouraging my bat research interests by locating caves and organising the survey trips documented in this paper. I would also like to thank the following people for their help and assistance with the preparation of this paper: Nina Ingle, Lawrence Heaney, Jodi Sedlock and David Waldien. 